\title{
In vitro permeability enhancement of curcumin across Caco-2 cells monolayers using
} electrospun xanthan-chitosan nanofibers

Faralli, Adele; Shekarforoush, Elhamalsadat; Ajalloueian, Fatemeh; Mendes, Ana Carina Loureiro; Chronakis, loannis S.

Published in:

Carbohydrate Polymers

Link to article, DOI:

10.1016/j.carbpol.2018.10.073

Publication date:

2019

Document Version

Peer reviewed version

Link back to DTU Orbit

Citation (APA):

Faralli, A., Shekarforoush, E., Ajalloueian, F., Mendes, A. C. L., \& Chronakis, I. S. (2019). In vitro permeability enhancement of curcumin across Caco-2 cells monolayers using electrospun xanthan-chitosan nanofibers.

Carbohydrate Polymers, 206, 38-47. https://doi.org/10.1016/j.carbpol.2018.10.073

\section{General rights}

Copyright and moral rights for the publications made accessible in the public portal are retained by the authors and/or other copyright owners and it is a condition of accessing publications that users recognise and abide by the legal requirements associated with these rights.

- Users may download and print one copy of any publication from the public portal for the purpose of private study or research.

- You may not further distribute the material or use it for any profit-making activity or commercial gain

- You may freely distribute the URL identifying the publication in the public portal 


\section{Accepted Manuscript}

Title: In vitro permeability enhancement of curcumin across Caco-2 cells monolayers using electrospun xanthan-chitosan nanofibers

Authors: Adele Faralli, Elhamalsadat Shekarforoush, Fatemeh Ajalloueian, Ana C. Mendes, Ioannis S. Chronakis

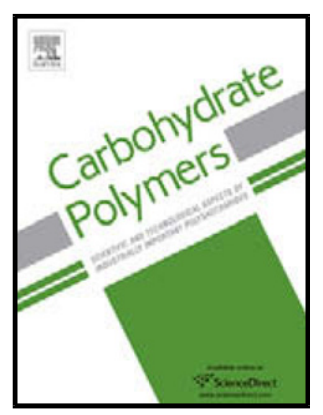

PII:

DOI: S0144-8617(18)31276-1

Reference: https://doi.org/10.1016/j.carbpol.2018.10.073 CARP 14205

To appear in:

Received date: $\quad 24-4-2018$

Revised date: $\quad 19-9-2018$

Accepted date: $\quad$ 24-10-2018

Please cite this article as: Faralli A, Shekarforoush E, Ajalloueian F, Mendes AC, Chronakis IS, In vitro permeability enhancement of curcumin across Caco-2 cells monolayers using electrospun xanthan-chitosan nanofibers, Carbohydrate Polymers (2018), https://doi.org/10.1016/j.carbpol.2018.10.073

This is a PDF file of an unedited manuscript that has been accepted for publication. As a service to our customers we are providing this early version of the manuscript. The manuscript will undergo copyediting, typesetting, and review of the resulting proof before it is published in its final form. Please note that during the production process errors may be discovered which could affect the content, and all legal disclaimers that apply to the journal pertain. 
Revised Manuscript -

Ms. Ref. No.: CARBPOL-D-18-01443R1

In vitro permeability enhancement of curcumin across Caco-2 cells monolayers using electrospun xanthan-chitosan nanofibers

Adele Faralli, Elhamalsadat Shekarforoush, Fatemeh Ajalloueian, Ana C. Mendes, Ioannis S. Chronakis *

Nano-BioScience Research Group, DTU-Food, Technical University of Denmark,

Kemitorvet, B202, 2800 Kgs. Lyngby, Denmark

*Corresponding author: Ioannis S. Chronakis

Tel: +4540206413

E-mail: ioach@food.dtu.dk 


\title{
Graphical abstract
}

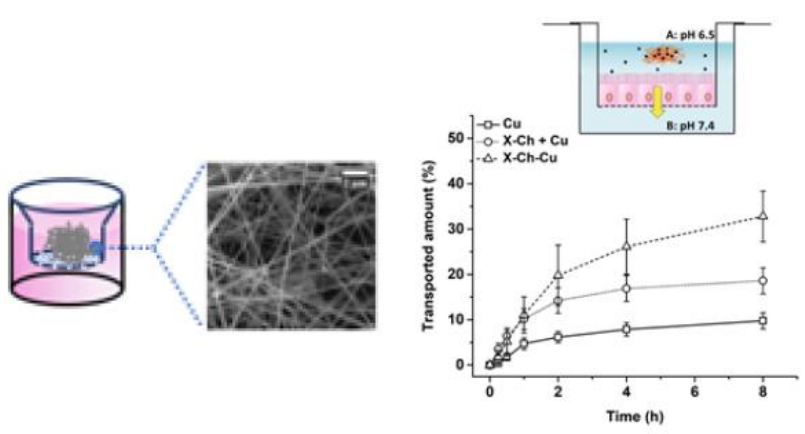

\section{Highlights (Revised)}

- Xanthan-chitosan mixture (X-Ch) forms ionically associated electrospun nanofibers (NF)

- X-Ch NF are stable in aqueous media, and encapsulate and deliver curcumin $(\mathrm{Cu})$

- X-Ch NF open Caco-2 cells tight junctions and enhance $\mathrm{Cu}$ transepithelial transport

- a 3.4-fold increase of $\mathrm{Cu}$ permeability observed in the presence of X-Ch nanofibers

- NF-epithelial cells interactions can be used to increase the oral uptake of bioactives

\begin{abstract}
Xanthan-Chitosan (X-Ch) polysaccharides nanofibers were prepared using electrospinning processing as an encapsulation and delivery system of curcumin $(\mathrm{Cu})$. The $\mathrm{X}-\mathrm{Ch}-\mathrm{Cu}$ nanofibers remained stable in aqueous HBSS medium at $\mathrm{pH} 6.5$ and $\mathrm{pH} 7.4$, mainly due to the ability of oppositely charged xanthan-chitosan polyelectrolytes to form ionically associated electrospun nanofibers. The xanthan-chitosan-curcumin nanofibers were incubated with Caco- 2 cells, and the cell viability, transepithelial transport and permeability properties across cell monolayers were investigated. After $24 \mathrm{~h}$ of incubation, the exposure of Caco- 2 cell monolayers to $\mathrm{X}$-Ch-Cu nanofibers resulted in a cell viability of $\sim 80 \%$. A 3.4-fold increase of curcumin permeability was observed when the polyphenol was loaded into X-Ch nanofibers, compared to the free curcumin. This increased in
\end{abstract}


vitro transepithelial permeation of curcumin without compromising cellular viability was induced by interactions upon contact between the nanofibers and the Caco-2 cells, leading to the opening of the tight junctions. The results obtained revealed that X-Ch nanofibers can be used for oral delivery applications of poorly water-soluble compounds at the gastrointestinal tract.

Keywords: Xanthan gum; Chitosan; Electrospinning; Fibers; Drug delivery; Curcumin

\section{Introduction}

Curcumin $(\mathrm{Cu})$ is a polyphenolic compound obtained from the dietary spice turmeric found in the Asian plant Curcuma longa. Due to its variety of biological properties such as anti-inflammatory, analgesic, potent antioxidant capacity (Aftab \& Vieira, 2009; Ak \& Gülçin, 2008), antimicrobial (Zorofchian Moghadamtousi et al., 2014) and anticarcinogenic (Perrone D, Ardito F,Giannatempo G, Dioguardi M,Troiano G, Lo Russo L, De Lillo A, Laino L, 2015), it has been used for centuries as dietary supplement and medicine (Gupta, Patchva, \& Aggarwal, 2013; R.A. Sharma, Gescher, \& Steward, 2005). Several studies in animal models and humans have reported that no serious toxicity is observed when curcumin is administered even at high doses, and clinical phase I studies have shown an high tolerance to repeated ingestions of $12 \mathrm{~g}$ of curcumin per day (Anand, Kunnumakkara, Newman, \& Aggarwal, 2007). Many of the curcumin benefits are also found at a cellular level as regulator of cellular enzymes such as cyclooxygenase and glutathione S-transferases, immunomodulation, inhibitor of several cell signaling pathways, and cell-cell adhesion (R.A. Sharma et al., 2005). Despite the established beneficial effects of curcumin as bioactive compound, curcumin has a poor aqueous solubility, intense staining color, and very low bioavailability (Anand et al., 2007; 
Dempe, Scheerle, Pfeiffer, \& Metzler, 2013). In fact, after oral administration of curcumin for up to $12 \mathrm{~g} /$ day, plasma and tissue levels of curcumin were found very low (in the range of nanogram per milliliter) (Anand et al., 2007). The major reasons causing such low gastrointestinal bioavailability of curcumin have been ascribed to poor absorption, chemical instability, rapid metabolism and systemic elimination, and accumulation within epithelial cells of the intestine (Anand et al., 2007; Wahlang, Pawar, \& Bansal, 2011). Furthermore, in the epathic and intestinal tissues of rats and humans, curcumin undergoes phase I and phase II metabolism (Hoehle, Pfeiffer, Sólyom, \& Metzler, 2006; Ricky A. Sharma, Steward, \& Gescher, 2007), similar to in vitro investigations (Dempe et al., 2013; Pfeiffer et al., 2007). A stepwise reduction of the olefinic double bonds of curcumin takes place in the phase I metabolism leading to tetrahydro-, hexahydro-, and octahydro-curcumin metabolites. A further biotransformation of curcumin and its metabolites involves the conjugation to glucuronic acid, sulfate, and glutathione under cell-free conditions and also in human Caco-2 cells (Usta et al., 2007). Moreover, it has also been documented that curcumin undergoes degradation in aqueous solution and at neutral pH, and hydrolyzed under alkaline pH (Tønnesen \& Karlsen, 1985; Y. J. Wang et al., 1997).

In order to overcome some of the major drawbacks of curcumin, different promising strategies have been undertaken aiming a higher permeability, resistance to metabolic processes, and enhancement of its solubility. A wide range of adjuvants such as piperine (Shoba et al., 1998), quercetin (Cruz-Correa et al., 2006), epigallocatechin-3-gallate (EGCG) (Balasubramanian \& Eckert, 2004) and genistein (Verma, Salamone, \& Goldin, 1997) have been proposed to modulate the permeability of curcumin and to increase its bioavailability. More recently, a wide variety of nanoand micro-delivery systems such as nanoparticles (Lee et al., 2014), micelles (Kocher, Schiborr, Behnam, \& Frank, 2015; Schiborr et al., 2014), liposomes, and phospholipid complexes (Cuomo et 
al., 2011) have emerged as solutions to enhance the bioavailability of various therapeutic agents (Anand et al., 2007). However, very few studies have been published reporting improved delivery properties of curcumin-loaded systems. Nanoencapsulation of curcumin using natural and synthetic polymers (Lee et al., 2014) and liposomal nanoparticles have been the most explored strategies because of their suitability for the encapsulation of a highly hydrophobic compound like curcumin, the prevention of curcumin degradation processes, and the enhancement of curcumin chemical stability. Lately, mucoadhesive nanostructured lipid carriers (NLCs) coated with polyethylene glycol 400 (PEG400) and polyvinyl alcohol (PVA) have been employed as a candidate system for oral delivery of curcumin (Chanburee \& Tiyaboonchai, 2017). The authors have demonstrated that polymer-coated curcumin-loaded NLCs improved curcumin water solubility more than 60-folds, as compared to curcumin dispersion. In addition, curcumin was protected from degradation processes, and the in vitro apparent permeability $\left(P_{a p p}\right)$ of curcumin across Caco-2 monolayers was higher than that obtained from uncoated NLCs (Chanburee \& Tiyaboonchai, 2017). Another approach to overcome the low curcumin oral bioavailability has been proposed by Frank et al.(Frank et al., 2017). The preparation of nanoscaled micellar formulations based on Tween 80 for curcumin delivery has revealed an increase on the apparent permeability through the intestinal barrier, resulting in a $P_{a p p}$ value of $2.11 \times 10^{-6} \mathrm{~cm} / \mathrm{s}$, compared to a $P_{a p p}$ value of $0.56 \times 10^{-6} \mathrm{~cm} / \mathrm{s}$ for free native curcumin (Frank et al., 2017). Furthermore, curcumin has been also encapsulated within electrospun fibers as delivery carriers, developed using phospholipid (Shekarforoush, Mendes, Baj, Beeren, \& Chronakis, 2017), as well as biopolymers such as gelatin (Deng, Kang, Liu, Feng, \& Zhang, 2017) and blends of amaranth protein isolate - pullulan (Blanco-Padilla, López-Rubio, Loarca-Piña, Gómez-Mascaraque, \& Mendoza, 2015). 
Electrospun fibers hold great promises as oral delivery systems. The large surface to volume ratio, the tunable surface functionality as well as the high encapsulation efficiency of the electrospun fibers, favor the diffusion and the dissolution rate of the bioactive compounds, and thus enhance their delivery. (Ignatious, Sun, Lee, \& Baldoni, 2010) (Li, Kanjwal, Lin, \& Chronakis, 2013). However, the delivery of the bioactive compounds at the intestine using electrospun fibers has not been assessed.

Furthermore, the Caco-2 cell model is used frequently to mimic the epithelial layer in the small intestine, and thus to evaluate the absorption of bioactive compounds in vitro assays (Artursson, Palm, \& Luthman, 2001). The Caco-2 cells, which are originally from a human colon cell line, can polarize and express receptors that resemble the intestinal absorptive cells found in the small intestine when cultured under specific conditions (Pinto et al., 1983). In vitro permeability studies have been employed the Caco-2 cells model, to assess the cytotoxicity and the permeation of bioactive compounds such as intestinal absorption of peptide drugs (Araújo \& Sarmento, 2013)(Araújo \& Sarmento, 2013). To the best of our knowledge, only few studies have assessed the intestinal delivery properties of bioactive compounds encapsulated within electrospun nanofibers using the Caco- 2 cells model. A recent study from our group using a Caco-2 cell permeability assay found that electrospun fish sarcoplasmic proteins (FSP) nanofibers could be used as novel oral delivery system of biopharmaceuticals (Stephansen, García-Díaz, Jessen, Chronakis, \& Nielsen, 2015). Lin et al. also studied the anticancer efficiency of magnetic electrospun chitosan nanofibers by assessing the Caco2 cell viability. It was found, that magnetic electrospun chitosan nanofibers have a potential therapeutic modality in tumor administration (Lin, Lin, \& Lin, 2012).

Chitosan is a cationic polysaccharide consisting of $\mathrm{N}$-acetyl glucosamine (GlcNAc) and glucosamine $(\mathrm{GlcN})$, and it has been widely used in the food, pharmaceutical and biomedical fields 
because of its biocompatibility, biodegradability, and mucoadhesivity (Borchard et al., 1996). One of the most interesting properties is the ability of chitosan to enhance gastrointestinal drug absorption (Portero, Remuñán-López, \& Nielsen, 2002). However, the chemical stability of chitosan is limited to a basic environment such as in the intestine and colon, whereas in neutral environments the polymer loses its charge and precipitate resulting in an ineffective absorption enhancer (Kowapradit et al., 2010). In order to chemically stabilize chitosan for applications that demands enhanced drug absorption, chitosan derivatives such as water-soluble quaternary ammonium chitosan (Kowapradit et al., 2010), and chitosan-glutamate (Portero et al., 2002), have been synthesized.

Alternatively, stable polyelectrolyte complexes of chitosan with xanthan have showed favorable properties as intestinal delivery systems. For instance, xanthan-chitosan hydrogels (Fukuda, Peppas, \& McGinity, 2006; Merlusca, Plamadeala, Girbea, \& Popa, 2016; Popa, Novac, Profire, Lupusoru, \& Popa, 2010; Sanem Argin-Soysala, Peter Kofinas, 2009) and xanthan-chitosan nanoparticles (Kulkarni, Wakte, \& Naik, 2015) have been studied as oral delivery carriers for a range of drug and bioactive compounds.

In the present study, we report the formation of electrospun xanthan-chitosan nanofibers as an encapsulation and delivery system of curcumin. The resulting curcumin-loaded nanofibers were incubated with Caco-2 cells, and the cell viability, transepithelial transport and permeability properties across cell monolayers were investigated. A consistent enhancement of the in vitro intestinal absorption of curcumin across cell monolayers was observed when the polyphenol was loaded into xanthan-chitosan nanofibers compared to the free curcumin.

\section{Materials and Methods}




\subsection{Methods}

Xanthan $(\mathrm{X})$, chitosan $(\mathrm{Ch})$, curcumin $(\mathrm{Cu})$ from Curcuma longa (Turmeric) and formic acid were obtained from Sigma-Aldrich (Denmark) and used as received. Xanthan gum from Xanthomonas campestris (product nr. G1253), with molecular weight $\sim 2000 \mathrm{kDa}$ was used (C. S. Wang, Natale, Virgilio, \& Heuzey, 2016). The selected chitosan polysaccharide (product nr. 448869) has a molecular weight of $\sim 28 \mathrm{kDa}$, degree of deacetylation (DD) of $89 \%$ and degree of polymerization (DP) of 175.

The human colon adenocarcinoma cell line Caco-2 [Caco-2] (ATCC® HTB-37'TM) was obtained from the American Type Culture Collection (Rockville, MD). Dulbecco's modified Eagle’s medium (DMEM) high glucose (4.5 g/L), L-glutamine (200 $\mathrm{mM})$, nonessential amino acids (100X), penicillin-streptomycin $(10,000 \mathrm{U} / \mathrm{mL}$ and $10 \mathrm{mg} / \mathrm{mL}$ in $0.9 \%$ sodium chloride, respectively), trypsinEDTA (10X), Dulbecco's Phosphate Buffered Saline 1X (DPBS) without calcium chloride and magnesium chloride, dimethyl sulfoxide $99.5 \%$ purity (DMSO), fluorescein sodium salt (FLUO), lucifer yellow dilithium salt (LY), , methanesulfonic acid, MES (1 M; pH 5.5-6.7), 4-(2hydroxyethyl)-1-piperazineethanesulfonic acid solution, HEPES (1 M; pH 7.0-7.6) were purchased from Sigma Aldrich (Brøndby, Denmark). Tissue culture 12-well plates and 12-mm polycarbonate cell culture inserts with an area of $1.12 \mathrm{~cm}^{2}$ and a pore size of $0.4 \mu \mathrm{m}$ were purchased from Corning Costar ${ }^{\circledR}$ Corporation. Fetal bovine serum (FBS) and Hanks' balanced salt solution (HBSS) with calcium and magnesium and without phenol red were obtained from Thermo Fisher Scientific (Roskilde, Denmark). CellTiter 96® AQueous One Solution Cell Proliferation Assay (MTS) was purchased from Promega Biotech AB (Sweden). 


\subsection{Preparation of polysaccharides mixtures}

Xanthan and Chitosan mixtures with curcumin were prepared by dissolving $3 \% \mathrm{w} / \mathrm{v}$ chitosan powder with $0.75 \% \mathrm{w} / \mathrm{v}$ xanthan powder in formic acid under vigorous stirring overnight at room temperature. Subsequently, curcumin $(2 \%$ w/v $)$ was added to the solubilized mixture of polysaccharides, and further stirred for $30 \mathrm{~min}$.

The electrical conductivity of xanthan, chitosan and xanthan-chitosan, and xanthan-chitosancurcumin solutions was determined using WTW LF323-B conductivity meter (WTW GmbH, Weilheim, Germany). All measurements were carried out at room temperature $\left(25 \pm 2{ }^{\circ} \mathrm{C}\right)$ in triplicate for each sample.

\subsection{Electrospinning setup}

The electrospinning setup included a high voltage generator (ES50P-10W, Gamma High Voltage Research, Inc., USA) to provide a voltage of $25 \mathrm{kV}$, and a syringe pump (New Era Pump Systems, Inc., USA) to feed the xanthan-chitosan and curcumin mixtures at a flow rate of $0.01 \mathrm{~mL} / \mathrm{min}$. A 21 G needle (Proto Advantage, Canada) with inner diameter $0.813 \mathrm{~mm}$ was used. Nanofibers were collected on a steel plate covered with aluminium foil placed at a distance of $10 \mathrm{~cm}$ from the edge of the needle. The electrospinning process was carried out at ambient conditions and samples were stored in an exicator until further analysis.

\subsection{Morphology}

The morphology of electrospun nanofibers was monitored using a Quanta FEG 3D scanning electron microscope (SEM) as described by Shekarforoush et al. (Shekarforoush, Faralli, Ndoni, 
Mendes, \& Chronakis, 2017). Briefly, a small amount of fibers was attached on SEM specimen by a double-sided carbon adhesive tape, and sputter coated with $6 \mathrm{~nm}$ of gold layer (Leica Coater ACE 200). Image J software (National Institute of Health, USA) was used to analyse the average diameter of the nanofibers (measured at 100 different points for each image).

\subsection{Encapsulation efficiency}

The encapsulation efficiency of $\mathrm{Cu}$ within $\mathrm{X}$-Ch electrospun nanofibers was determined by extracting the $\mathrm{Cu}$ from the fibers using methanol in a sonication bath for $30 \mathrm{~min}$, and collecting the amount of loaded curcumin from supernatants after centrifugation at $4500 \mathrm{rpm}$ for $15 \mathrm{~min}$. The concentration of curcumin in the supernatant was determined using a UV-vis spectrometry (Nanodrop OneC, Thermo Fisher Scientific, Roskilde, DK), by recording its absorbance at 280 and $420 \mathrm{~nm}$. Standard curves for curcumin were prepared with concentrations ranging from $0-100 \mu \mathrm{g} / \mathrm{mL}$. The encapsulation efficiency was calculated using the following equation:

$$
\% \text { Encapsulation Efficiency }=\frac{\text { Calculated curcumin concentration }}{\text { Theoretical curcumin concentration }} \times \mathbf{1 0 0}
$$

\subsection{In vitro release of curcumin}

The in vitro release of curcumin from xanthan-chitosan nanofibers was evaluated by suspending $3.0 \mathrm{mg}$ of $\mathrm{X}-\mathrm{Ch}-\mathrm{Cu}$ fibers in $2 \mathrm{~mL}$ pre-warmed HBSS at $\mathrm{pH} 6.5$ and $\mathrm{pH} 7.4$, respectively. The curcumin release was conducted for a time interval of $8 \mathrm{~h}$ at $37^{\circ} \mathrm{C}$ with continuous mild agitation using an orbital shaker (100 rpm). Supernatant aliquots were withdrawn and analyzed by UV-vis spectrometry by recording the curcumin absorption at 280 and $420 \mathrm{~nm}$. The cumulative amount of curcumin released from $\mathrm{X}-\mathrm{Ch}-\mathrm{Cu}$ nanofibers was then considered as the maximum releasable curcumin from the nanofibers structure. 


\subsection{Caco-2 cell culture and subculture}

Caco- 2 cells were routinely seeded at a concentration of $1.0 \times 10^{5}$ cells $/ \mathrm{mL}$ in $\mathrm{T}-75 \mathrm{~cm}^{2}$ flasks and incubated at $37{ }^{\circ} \mathrm{C}$ in a humidified atmosphere of $5 \% \mathrm{CO}_{2}$. The complete cell medium consisted of high glucose DMEM containing 10\% heat-inactivated FBS, 2 mM L-glutamine, $1 \%$ nonessential amino acids, $100 \mathrm{U} / \mathrm{mL}$ penicillin, and $100 \mu \mathrm{g} / \mathrm{mL}$ streptomycin. The medium was renewed every second day until cells reached approximately $90 \%$ confluence. Cells were passaged at a subcultivation ratio of $1: 4$ by treatment with $0.25 \%$ trypsin $-0.53 \mathrm{mM}$ EDTA solution for $10 \mathrm{~min}$ at $37{ }^{\circ} \mathrm{C}$. After trypsinization, the cells were suspended in complete growth medium and centrifuged for 5 min at $1000 \mathrm{rpm}$. After supernatant removal, the pellet was suspended in the growth medium and the cell concentration was determined with ORFLO Moxi Z Mini Automated Cell Counter using Type S cassette (Biofrontier Technology, Singapore). All Caco-2 cells were used between passages 6 - 12.

\subsection{Compounds and electrospun nanofibers used for the cell studies}

Xanthan-chitosan (X-Ch) and curcumin-loaded xanthan-chitosan (X-Ch-Cu) electrospun nanofibers were tested with Caco-2 cells to evaluate their toxicity and to determine the apparent permeability coefficient $\left(\mathrm{P}_{\mathrm{app}}\right)$ of curcumin loaded into the nanofibers, and as free compound. Before testing the nanofibers with Caco-2 cells, the collected fibers were kept under air stream for 3 days allowing complete formic acid evaporation.

Besides curcumin, the transepithelial transport of fluorescein (FLUO) and Lucifer yellow (LY) across Caco-2 cell monolayers were also investigated as markers for intestinal epithelial permeability and integrity. The physicochemical properties and the expected mechanisms involved on molecules permeation across Caco-2 monolayers are listed in Table $\mathbf{1 .}$ 


\section{Table 1.}

Physicochemical properties of compounds and their expected transepithelial transport across Caco-2 cell monolayers.

\begin{tabular}{|c|c|c|c|c|c|}
\hline Compound & $\begin{array}{l}\text { MW } \\
\text { (Da) }\end{array}$ & $\operatorname{ACDLogPa}$ & $\operatorname{ACDpK}_{\mathrm{a}}{ }^{\mathrm{a}}$ & $\begin{array}{l}\lambda_{\mathrm{Abs}} \mathrm{b}^{\mathrm{b}} \\
(\mathbf{n m})\end{array}$ & $\begin{array}{c}\text { Transepithelial transport } \\
\text { across Caco-2 cell monolayers }\end{array}$ \\
\hline Curcumin, $\mathrm{Cu}$ & 368.39 & 3.07 & 8.11 & $\begin{array}{c}280 \text { and } \\
420\end{array}$ & $\begin{array}{l}\text { Extremely poor } \\
\text { gastrointestinal } \\
\text { absorption. } \\
\text { - Undergoes phase I and } \\
\text { II bio-transformations. } \\
\text { - } \\
\text { Passive transport. }\end{array}$ \\
\hline $\begin{array}{l}\text { Fluorescein, } \\
\text { FLUO }\end{array}$ & 376.27 & 4.81 & 4.40 & 490 & $\begin{array}{l}\text { - } \quad \text { pH-dependent transport. } \\
\text { - } \text { Influx ratio 10. }{ }^{\mathbf{d}} \\
\text { - } \quad \text { Carrier-mediated } \\
\text { unidirectional } \\
\text { transcellular transport. }{ }^{\mathbf{d}, \mathbf{e}}\end{array}$ \\
\hline $\begin{array}{c}\text { Lucifer } \\
\text { Yellow, LY }\end{array}$ & 457.25 & -5.06 & -0.9 & 430 & $\begin{array}{l}\text { - } \mathrm{pH} \text {-indipendent } \\
\text { transport. } \\
\text { - No observed influx- } \\
\text { efflux. } \\
\text { - Paracellular pathway. } \mathbf{d , f}\end{array}$ \\
\hline
\end{tabular}

${ }^{\mathrm{a}}$ Values for $\log \mathrm{P}$ and $\mathrm{pK}_{\mathrm{a}}$ were obtained from the ACD database.

${ }^{b}$ Experimentally determined wavelength.

${ }^{\text {c }}$ Results published by Dempe et al.(Dempe et al., 2013)

${ }^{\mathbf{d}}$ Results published by Konishi et al.(KONISHI, HAGIWARA, \& SHIMIZU, 2002)

e Results published by Berginc et al.(Berginc, Žakelj, Levstik, Uršič, \& Kristl, 2007)

${ }^{f}$ Results published by Hashimoto et al.(Hashimoto, Matsunaga, \& Shimizu, 1994) 


\subsection{Caco-2 cell viability assay}

The in vitro Caco-2 cell viability after treatment with free curcumin $(\mathrm{Cu})$, xanthan-chitosan nanofibers $(\mathrm{X}-\mathrm{Ch})$, and curcumin-loaded xanthan-chitosan nanofibers (X-Ch- $\mathrm{Cu}$ ) was evaluated by using the MTS [3-(4,5-dimethylthiazol-2-yl)-5-(3-carboxymethoxyphenyl)-2-(4-sulfophenyl)-2Htetrazolium inner salt] colorimetric bioassay. A stock solution of $50 \mathrm{mM}$ curcumin was prepared in $0.5 \mathrm{M} \mathrm{NaOH}$ and immediately diluted to $5 \mathrm{mM}$ in PBS. The curcumin solution was filtered through sterile-filters (with a $0.22 \mu \mathrm{m}$ pore size). In a 96-well plate, a concentration of $2.0 \times 10^{4}$ cells/100 $\mu \mathrm{L}$ were seeded in a complete growth medium and incubated for 2 days at $37^{\circ} \mathrm{C}$ in a humidified atmosphere of $5 \% \mathrm{CO}_{2}$. Then the cells were washed with PBS, and the complete medium was renewed. Caco-2 cells were incubated with free curcumin solution (150 and $500 \mu \mathrm{M}), \mathrm{X}-\mathrm{Ch}$ nanofibers $(0.5 \mathrm{mg}), \mathrm{X}-\mathrm{Ch}-\mathrm{Cu}$ nanofibers $(0.5 \mathrm{mg})$, and PBS as a control. Caco-2 cells were incubated for one day at $37{ }^{\circ} \mathrm{C}$ in a humidified atmosphere of $5 \% \mathrm{CO}_{2}$. The following day, the nanofibers were removed from the wells, cells were washed with PBS and the medium was renewed $(100 \mu \mathrm{L}) .20 \mu \mathrm{L}$ MTS solution was added to each well under dark conditions. After $3 \mathrm{~h}$ incubation at $37{ }^{\circ} \mathrm{C}$, the absorbance of the reduced MTS (formazan product) was recorded at $490 \mathrm{~nm}$ through a well plate reader (Wallac 1420 Victor2 Multilabel Counter, Perkin Elmer, Waltham, MA).

\subsection{Transepithelial transport experiments}

The transport of free fluorescein (FLUO), free lucifer yellow (LY), free curcumin (Cu), free curcumin in presence of xanthan-chitosan nanofibers $(\mathrm{X}-\mathrm{Ch}+\mathrm{Cu})$, and curcumin-loaded xanthanchitosan nanofibers $(\mathrm{X}-\mathrm{Ch}-\mathrm{Cu})$ across $\mathrm{Caco}-2$ cell monolayers were investigated according to the protocol reported by Artursson et al. (Hubatsch, Ragnarsson, \& Artursson, 2007). The transepithelial transport experiments were performed in both apical-to-basolateral (AB, absorptive) and basolateral- 
to-apical (BA, secretory) directions, under a proton gradient. In fact, in order to mimic the acidic microclimate of the small intestine, an apical $\mathrm{pH}$ of 6.5 and a basolateral $\mathrm{pH}$ of 7.4 were used. Briefly, $1.0 \times 10^{5}$ cells/insert were seeded onto pre-wetted $12-\mathrm{mm}$ polycarbonate cell culture inserts (area of $1.12 \mathrm{~cm}^{2}$ and a pore size of $0.4 \mu \mathrm{m}$ ). The apical and basolateral compartments were filled with 0.5 $\mathrm{mL}$ cell suspension and $1.5 \mathrm{~mL}$ complete medium, respectively. The Caco-2 cells plates were incubated overnight at $37{ }^{\circ} \mathrm{C}$ in a humidified atmosphere of $5 \% \mathrm{CO}_{2}$. The day after, the growth medium was replaced in both compartments and the plates were incubated for 21 days at $37^{\circ} \mathrm{C}$ in a humidified atmosphere of $5 \% \mathrm{CO}_{2}$, renewing the complete growth medium every second day. For the $\mathrm{AB}$ transport experiments, donor solutions of fluorescein, lucifer yellow, and curcumin at a concentration of $11 \mathrm{mM}, 9.57 \mathrm{mM}$, and $1.65 \mathrm{mM}$, respectively were prepared in sterile-filter HBSS at pH 6.5 buffered with $10 \mathrm{mM}$ MES. Again, donor solutions of fluorescein, lucifer yellow, and curcumin at a concentration of $10.3 \mathrm{mM}, 9 \mathrm{mM}$, and $1.55 \mathrm{mM}$, respectively were prepared in sterilefilter HBSS at pH 7.4 buffered with $25 \mathrm{mM}$ HEPES to evaluate their BA transport across cell monolayers. X-Ch and X-Ch-Cu nanofibers have been also investigated, and $3.0 \mathrm{mg}$ of nanofibers for $\mathrm{AB}$ transport and $9.0 \mathrm{mg}$ of nanofibers for BA transport were used. After 21 days cell growth, the complete DMEM medium was removed from the Caco-2 cell monolayers and was replaced with HBSS at pH 6.5 and $\mathrm{pH} 7.4$ at the apical and basolateral compartments, respectively. For the AB transport studies, $1.5 \mathrm{~mL}$ HBSS was used in the basolateral side and $0.55 \mathrm{~mL}$ of each donor solutions and/or nanofibers were added to the apical side. Immediately, $50 \mu \mathrm{L}$ aliquots were withdrawn from each donor compartment (time=0). The aliquots were then withdrawn from the acceptor side at different time intervals, and the volume was replaced with fresh pre-warmed HBSS at pH 7.4 maintaining the well plates at $37{ }^{\circ} \mathrm{C}$ in a humidified atmosphere of $5 \% \mathrm{CO}_{2}$. A final aliquot from the donor chamber was taken as last time point. BA transport studies were conducted by using $0.5 \mathrm{~mL}$ HBSS at pH 6.5 in the apical side, and $1.55 \mathrm{~mL}$ of donor solution and/or nanofibers in the basolateral 
chamber. Again, a $50 \mu \mathrm{L}$ aliquot was immediately withdrawn from the donor compartment (time=0), and the plates were kept at $37^{\circ} \mathrm{C}$ in a humidified atmosphere of $5 \% \mathrm{CO}_{2}$. At different time intervals, $50 \mu \mathrm{L}$ aliquots from the acceptor compartment were collected and the volume was replaced with fresh pre-warmed HBSS at pH 6.5. A final aliquot was taken from the donor side at last time point. During the transport experiments, all cell media and solutions were pre-warmed at $37^{\circ} \mathrm{C}$. Each transport experiment was performed for a time interval of $8 \mathrm{~h}$, in triplicates $(\mathrm{n}=3)$. After $8 \mathrm{~h}$ transport studies both apical and basolateral chambers were washed twice with PBS, and cell monolayers were detached from the insert membrane with $0.25 \%$ trypsin $-0.53 \mathrm{mM}$ EDTA solution for 10 min at 37 ${ }^{\circ} \mathrm{C}$. The collected Caco-2 cell lysates were centrifuged for $5 \mathrm{~min}$ at $1000 \mathrm{rpm}$ and supernatants were discarded. Furthermore, the semipermeable membranes were carefully removed from the insert using a scalpel and collected into Eppendorf tubes in $500 \mu \mathrm{L} \mathrm{HBSS}$ at pH 6.5 (apical conditions). Cell pellets as well were re-suspended in $500 \mu \mathrm{L}$ HBSS at pH 6.5 and both cells and membranes were sonicated for $3 \mathrm{~h}$ using an ultrasonic bath (Branson Ultrasonic Corp., VWR, Denmark). The collected samples were then centrifuged for $5 \mathrm{~min}$ at $10000 \mathrm{rpm}$ and the supernatants were analyzed by UVvis spectroscopy. The same procedure was used to quantify the amount of curcumin adsorbed (X-Ch $+\mathrm{Cu})$ or encapsulated $(\mathrm{X}-\mathrm{Ch}-\mathrm{Cu})$ into the nanofibers at the end of transport experiments. The tested nanofibers were removed from the donor chamber and suspended in $500 \mu \mathrm{L}$ of HBSS (pH 6.5 for AB transport and $\mathrm{pH} 7.4$ for $\mathrm{BA}$ transport). After sonication and centrifugation, the curcumin found in the supernatants was quantified by absorbance measurement.

\subsection{Measurement of transepithelial electrical resistance (TEER)}

The Transepithelial Electrical Resistance (TEER) was measured at room temperature before and after permeability experiments with an epithelial volt-ohmmeter equipped with an STX2 "chopstick" electrodes (EVOM2 ${ }^{\mathrm{TM}}$, World Precision Instruments, Sarasota, FL, USA). Before measuring the 
resistance values of each well, the cell monolayers and the basolateral chamber were washed twice with pre-warmed HBSS at $\mathrm{pH} 6.5$ and HBSS at $\mathrm{pH} 7.4$, respectively. The resistance values of the semipermeable membrane without cells ( $\mathrm{R}_{\text {BLANK}}$ ) were recorded and subtracted from the resistance values obtained from the measurement of cell monolayers on the semipermeable membrane ( $\left.\mathrm{R}_{\text {TOTAL }}\right)$. The specific cell resistance values ( $\mathrm{R}_{\mathrm{TISSUE}}$ ) were obtained from the following equation:

$$
\operatorname{R}_{\text {TISSUE }}(\Omega)=\operatorname{R}_{\text {TOTAL }}(\Omega)-\operatorname{R}_{\text {BLANK }}(\Omega)
$$

TEER values of cellular monolayers were expressed in $\Omega \times \mathrm{cm}^{2}$ and calculated according to the following equation:

$$
\operatorname{TEER}_{\text {TISSUE }}\left(\Omega \mathrm{cm}^{2}\right)=\mathrm{R}_{\text {TISSUE }}(\Omega) \times \operatorname{AMEMBRANE}_{\left(\mathrm{cm}^{2}\right)}
$$

\subsection{Quantification of compounds}

Donor solutions of fluorescein, lucifer yellow, and curcumin were prepared and sterile-filter in HBSS at pH 6.5 and pH 7.4 to perform transepithelial studies. Standard curves of FLUO, LY, and Cu dissolved in HBSS at $\mathrm{pH} 6.5$ and $\mathrm{pH} 7.4$ were obtained through UV-vis spectroscopic analysis (Nanodrop One ${ }^{\mathrm{C}}$, Thermo Fisher Scientific, Roskilde, DK). The aliquots withdrawn from the donor and acceptor compartments during transport experiments across cell monolayers were quantified by UV-vis spectrometry recording the absorbance values at $490 \mathrm{~nm}$ for FLUO, $430 \mathrm{~nm}$ for LY, and 280

$\mathrm{nm}$ and $420 \mathrm{~nm}$ for $\mathrm{Cu}$ (Table 2). The amount of each compound transported across the cell monolayers within a time interval of $8 \mathrm{~h}$ was calculated for both apical-to-basolateral (AB) and basolateral-to-apical (BA) directions. FLUO, LY, and curcumin that remained entrapped within cell monolayers, insert membranes and nanofibers were likewise quantified at the end of permeability studies after sonication treatment. 


\section{Table 2}

Tested compounds and relative concentrations used for transepithelial transport studies (AB and BA) across Caco-2 cell monolayers.

\begin{tabular}{|c|c|c|c|c|c|}
\hline & \multicolumn{2}{|c|}{ AB transport } & \multicolumn{2}{|c|}{ BA transport } & \\
\hline Compound & {[]$_{\mathbf{A}}(\boldsymbol{\mu M})$} & $\mathbf{V}_{\mathbf{A}}(\mu \mathrm{L})$ & {[]$_{\mathbf{B}}(\boldsymbol{\mu M})$} & $\mathbf{V}_{\mathbf{B}}(\boldsymbol{\mu} \mathbf{L})$ & $\begin{array}{l}\lambda_{\mathrm{Abs}} \\
(\mathbf{n m})\end{array}$ \\
\hline Fluorescein, FLUO & 1000 & 50 & 1000 & 150 & 490 \\
\hline Lucifer Yellow, LY & 870 & 50 & 870 & 150 & 430 \\
\hline Free Curcumin, $\mathrm{Cu}$ & 150 & 50 & & 150 & $\begin{array}{l}280 \\
\text { and } \\
420\end{array}$ \\
\hline $\begin{array}{c}\text { Free Curcumin }+ \\
\text { nanofibers, } \mathrm{Cu}+\mathrm{X}-\mathrm{Ch}\end{array}$ & $\begin{array}{c}150 \mu \mathrm{M}+3.0 \\
\mathrm{mg} \text { fibers }\end{array}$ & 50 & $\begin{array}{c}150 \mu \mathrm{M}+9.0 \\
\mathrm{mg} \text { fibers }\end{array}$ & 150 & $\begin{array}{l}280 \\
\text { and } \\
420\end{array}$ \\
\hline $\begin{array}{l}\text { Curcumin loaded } \\
\text { nanofibers, } \\
\text { X-Ch-Cu }\end{array}$ & $\begin{array}{c}3.0 \mathrm{mg} \text { fibers } \\
(150 \mu \mathrm{M} \\
\text { releasable } \\
\mathrm{Cu})\end{array}$ & 0 & $\begin{array}{c}9.0 \mathrm{mg} \\
\text { fibers } \\
(150 \mu \mathrm{M} \\
\text { releasable } \\
\mathrm{Cu})\end{array}$ & 0 & $\begin{array}{l}280 \\
\text { and } \\
420\end{array}$ \\
\hline
\end{tabular}


2.13. FLUO, $\mathrm{LY}$, and $\mathrm{Cu}$ distribution after transport experiments and mass balance

After transport experiments in both $\mathrm{AB}$ and $\mathrm{BA}$ directions, the amount of each compound in the apical and basolateral compartments was quantified by UV-vis spectrometry. Donor concentrations at time $=0\left(\mathrm{C}_{\mathrm{D}, \mathrm{t}=0 \mathrm{~h}}\right)$, donor and acceptor concentrations at time $=8 \mathrm{~h}\left(\mathrm{C}_{\mathrm{D}, \mathrm{t}=8 \mathrm{~h}}\right.$ and $\mathrm{C}_{\mathrm{A}, \mathrm{t}=8 \mathrm{~h}}$, respectively $)$, compound concentrations remained within cell monolayer at time $=8 \mathrm{~h}\left(\mathrm{C}_{\mathrm{Caco}-2, \mathrm{t}=8 \mathrm{~h}}\right)$, membrane filters at time $=8 \mathrm{~h}\left(\mathrm{C}_{\text {insert }, \mathrm{t}=8 \mathrm{~h}}\right)$, and adsorbed or encapsulated into nanofibers at time $=8 \mathrm{~h}\left(\mathrm{C}_{\text {fibers, } \mathrm{t}=8 \mathrm{~h}}\right)$ were experimentally measured by UV-vis spectroscopy. Therefore, the mass balance of each compound was calculated as follow:

$$
\mathrm{C}_{\mathrm{D}, \mathrm{t}=0 \mathrm{~h}}=\mathrm{C}_{\mathrm{D}, \mathrm{t}=8 \mathrm{~h}}+\mathrm{C}_{\mathrm{A}, \mathrm{t}=8 \mathrm{~h}}+\mathrm{C}_{\mathrm{Caco}-2, \mathrm{t}=8 \mathrm{~h}}+\mathrm{C}_{\text {insert }, \mathrm{t}=8 \mathrm{~h}}+\left(\mathrm{C}_{\text {fibers }, \mathrm{t}=8 \mathrm{~h}}\right)
$$

Mass balance values of $>90 \%$ were found for all tested compounds.

2.14. Calculation of the apparent permeability coefficients $\mathrm{P}_{\mathrm{app}}, \mathrm{AB}$ and $\mathrm{P}_{\mathrm{app}}$, В A.

The absorptive apparent permeability coefficient $\left(\mathrm{P}_{\mathrm{app}}, \mathrm{AB}\right)$ and the secretory apparent permeability coefficient $\left(\mathrm{P}_{\mathrm{app}}, \mathrm{BA}\right)$ were determined according to the equation:

$$
\mathrm{P}_{\mathrm{app}}=\frac{\mathrm{dC}}{\mathrm{dt}} * \frac{\mathrm{V}}{\mathrm{A} * \mathrm{C}_{0}}
$$

where, $d C / d t(\mu \mathrm{M} / \mathrm{s})$ is the change in concentration on the acceptor chamber over time; $V\left(\mathrm{~cm}^{3}\right)$ is the volume of the solution in the acceptor compartment; $A\left(\mathrm{~cm}^{2}\right)$ is the area of the semipermeable membrane; $C_{0}(\mu \mathrm{M})$ is the initial concentration in the donor chamber. The results presented in this study were the averages of three experiments and were expressed as the mean \pm standard deviation.

\section{Results and Discussions}




\subsection{Electrospinning of Xanthan - Chitosan nanofibers}

Xanthan-Chitosan nanofibers were obtained by electrospinning mixtures of $\mathrm{X}$ at the concentration of $0.75 \% \mathrm{w} / \mathrm{v}$ with $3 \% \mathrm{w} / \mathrm{v}$ Ch dissolved in formic acid (Fig. 1). The obtained nanofibrous structures are composed of individual, uniform and randomly oriented fibers with an average diameter of $750 \pm$ $250 \mathrm{~nm}$. Note that chitosan solution $(3 \% \mathrm{w} / \mathrm{v})$ in formic acid (without xanthan) could not be electrospun into fibers. The average diameter of electrospun xanthan-chitosan nanofibers slightly increased to $900 \pm 440 \mathrm{~nm}$ with the addition of $2 \% \mathrm{w} / \mathrm{v}$ curcumin (Fig. 1). The encapsulation efficiency of $\mathrm{Cu}$ within $\mathrm{X}-\mathrm{Ch}$ nanofibers was $69.4 \pm 4.1 \%$.

Furthermore, the electrical conductivity of $0.75 \% \mathrm{w} / \mathrm{v}$ xanthan and $3 \% \mathrm{w} / \mathrm{v}$ chitosan solutions in formic acid was $0.19+0.01 \mathrm{mS} / \mathrm{cm}$ and $1.23+0.06 \mathrm{mS} / \mathrm{cm}$, respectively. However the electrical conductivity of the X-Ch mixture $(0.75-3 \%$ w/v) and X-Ch-Cu $(0.75-3-2 \%$ w/v) was enhanced significantly to $5.5+0.08 \mathrm{mS} / \mathrm{cm}$ and $5.71+0.09 \mathrm{mS} / \mathrm{cm}$, respectively, as an indication of an organizational change in the structure of the polysaccharides mixture. Such an increase of the solution conductivity induces greater transfer of the surface charges of the polysaccharides jet, enhanced electrostatic repulsion, promoting elongation, stretching, and the formation of electrospun $\mathrm{X}-\mathrm{Ch}-\mathrm{Cu}$ nanofibers.(Frenot \& Chronakis, 2003) (Vega-Lugo and Lim, 2012).

Moreover, the X-Ch-Cu nanofibers remained stable in aqueous HBSS medium at different $\mathrm{pH}$ (6.5 and $\mathrm{pH}$ 7.4), due to the ability of oppositely charged xanthan-chitosan mixture to form ionically associated electrospun nanofibers, (Shekarforoush, Ajalloueian, Zeng, Mendes, Chronakis, 2018). The features of xanthan-chitosan-curcumin nanofibers were not further examined in the present study. 


\subsection{In vitro release study}

The cumulative release profile of curcumin from the electrospun $\mathrm{X}$-Ch nanofibers at two different $\mathrm{pH}\left(7.4\right.$ and 6.5) at $37^{\circ} \mathrm{C}$ is shown in Fig. 2. A sustained release of curcumin from X-Ch nanofibers was observed over a period of $4 \mathrm{~h}$ for both $\mathrm{pH}$ with no significant burst effect. Approximately $4 \%$ of curcumin was released from $\mathrm{X}$-Ch nanofibers after $4 \mathrm{~h}$ and beyond that, no significant changes in the cumulative release of $\mathrm{Cu}$ were found up to $8 \mathrm{~h}$. The slow release of curcumin is due to its hydrophobic nature. FTIR studies confirmed the absence of physical or chemical interactions between curcumin molecules and xanthan-chitosan fibers matrix (data not shown).

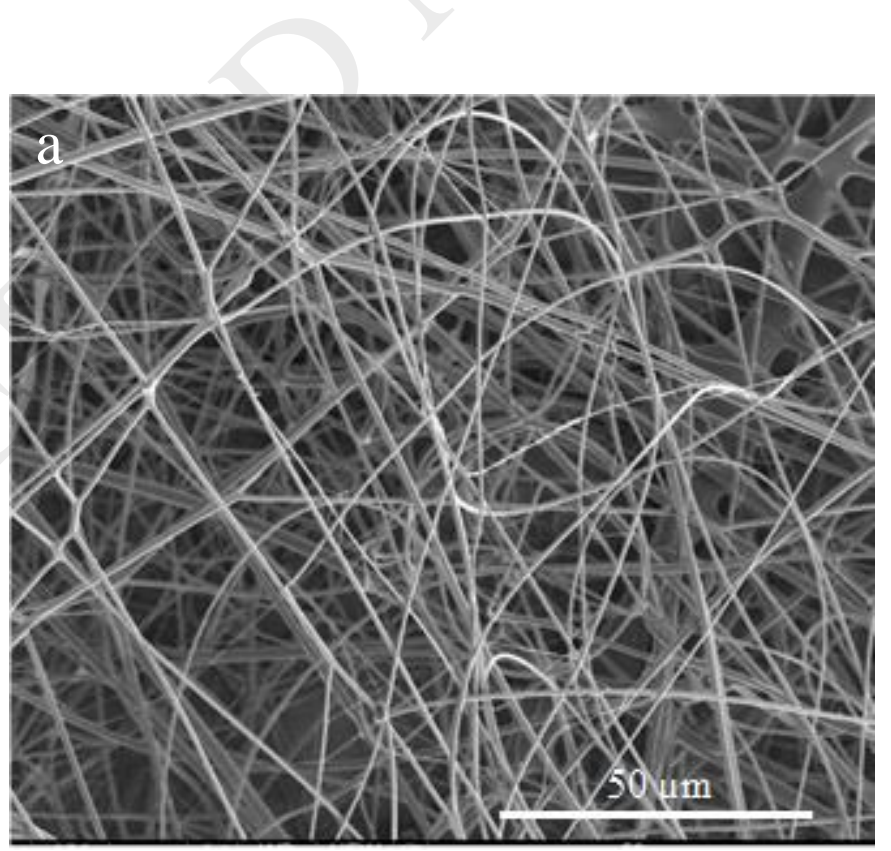




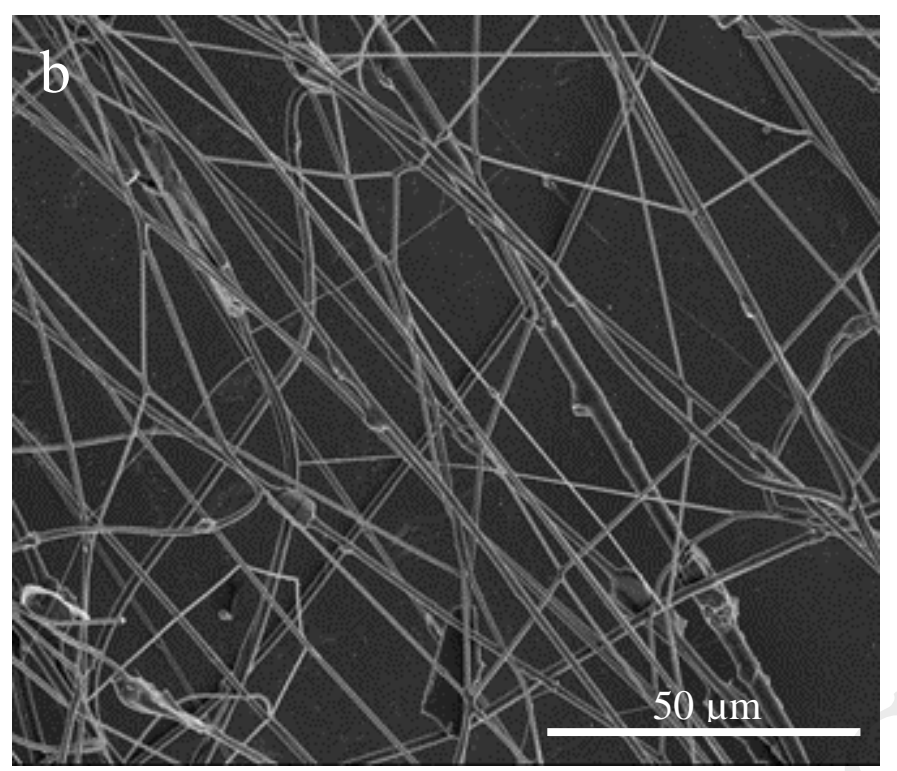

Fig.1. SEM images of electrospun nanofibers of (a) xanthan-chitosan $(0.75-3 \% \mathrm{w} / \mathrm{v})$ and (b) xanthan-chitosan-curcumin $(0.75-3-2 \% \mathrm{w} / \mathrm{v})$ mixtures in formic acid. 


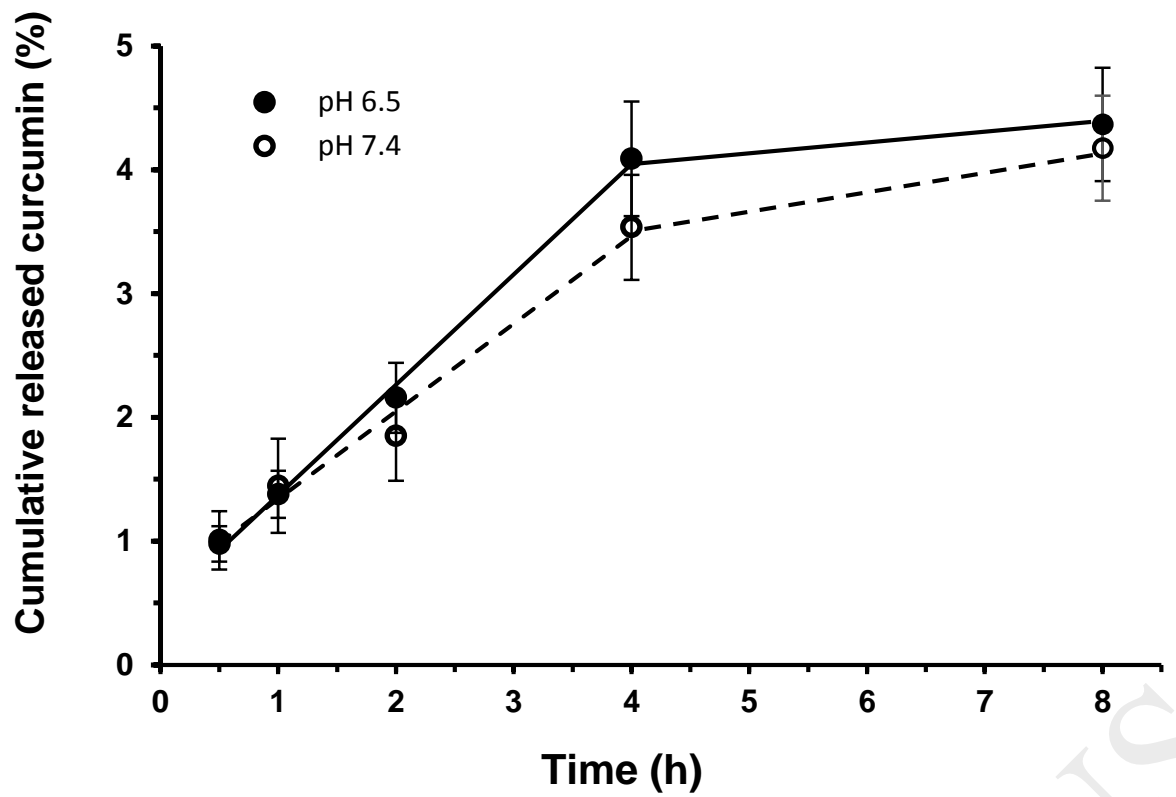

Fig. 2. Release of curcumin from $\mathrm{X}-\mathrm{Ch}-\mathrm{Cu}$ nanofibers suspended in HBSS medium at pH 6.5 (solid line), and pH 7.4 (dashed line) at $37^{\circ} \mathrm{C}$. All data are the mean $\pm \mathrm{SD}$ of three independent experiments.

\subsection{Caco-2 cell studies}

In our previous studies, we have observed a significant effect on the permeation of a model protein (insulin) across Caco-2 cells upon contact with electrospun fish sarcoplasmic protein fibers (FSP) (Stephansen et al., 2015). Encapsulation of insulin into the FSP fibers provided protection against chymotrypsin degradation (suitable for oral administration), and the interactions between fibers and epithelial cells led to opening of the tight junction, which promoted an increased transepithelial transport of insulin without compromising cellular viability (Stephansen et al., 2015). This approach of using electrospun nanofibers is superior to the typical approach of administering solely nanoparticles for intestinal delivery of bioactives (typically nanoparticles are distributed over the entire surface, having a short retention time, and low bioactive penetration). 
The Caco-2 cell system has been recommended by the US Food and Drug Administration (FDA) as being an established in vitro cell model for the prediction of oral drug absorption and drug transport mechanism across human differentiated epithelial cell monolayers (Artursson et al., 2001). The human colon carcinoma cell line Caco- 2 was chosen because of the many similar features with the intestinal epithelial cells. In fact, Caco-2 cells can slowly differentiates into monolayers forming microvilli and tight junctions at the apical side, and expressing brush border enzymes for phase I and phase II metabolism and transport proteins (Hubatsch et al., 2007; Naruhashi et al., 2011; Yee, 1997). In the present study, the Caco-2 cell system was selected as a tool to investigate the in vitro absorption and the transports (both apical-to-basolateral (AB) and basolateral-to-apical (BA)) of curcumin across cell monolayers.

\subsection{Evaluation of cell viability}

The viability of Caco-2 cells after 24-h treatment with free curcumin $(\mathrm{Cu})$, Xanthan-Chitosan nanofibers (X-Ch), curcumin-loaded Xanthan-Chitosan nanofibers (X-Ch-Cu), and PBS was evaluated through MTS bioassay (Fig. 3). The MTS tetrazolium compound is reduced by cells into a colored formazan product that is soluble in tissue culture medium and quantified recording its absorbance at $490 \mathrm{~nm}$. This conversion is accomplished by dehydrogenase enzymes in metabolically active cells, therefore MTS conversion is directly proportional to the number of living cells (Cory,

Owen, Barltrop, \& Cory, 1991). The incubation of Caco-2 cells with $0.5 \mathrm{mg}$ X-Ch nanofibers, $0.5 \mathrm{mg}$ $\mathrm{X}-\mathrm{Ch}-\mathrm{Cu}$ nanofibers, and free curcumin $(\mathrm{Cu}, 150 \mu \mathrm{M})$ was non-toxic to the cells, and cell viability was found to be $\geq 80 \%$. By contrast, when cells were exposed to $500 \mu \mathrm{M}$ free curcumin, the cell viability value was decreased to $\sim 20 \%$, indicating a concentration-dependent toxic effect of curcumin in cell viability. According to the encapsulation efficiency of curcumin into nanofibers and the in vitro release profile of curcumin from $\mathrm{X}-\mathrm{Ch}-\mathrm{Cu}$ nanofibers at $\mathrm{pH} 7.4$, the amount of releasable 
curcumin from $0.5 \mathrm{mg} \mathrm{X}-\mathrm{Ch}-\mathrm{Cu}$ nanofibers was assumed to be $150 \mu \mathrm{M}$. Therefore, this concentration was selected to determine the apical-to-basolateral and basolateral-to-apical transports of curcumin across Caco- 2 cell monolayers.

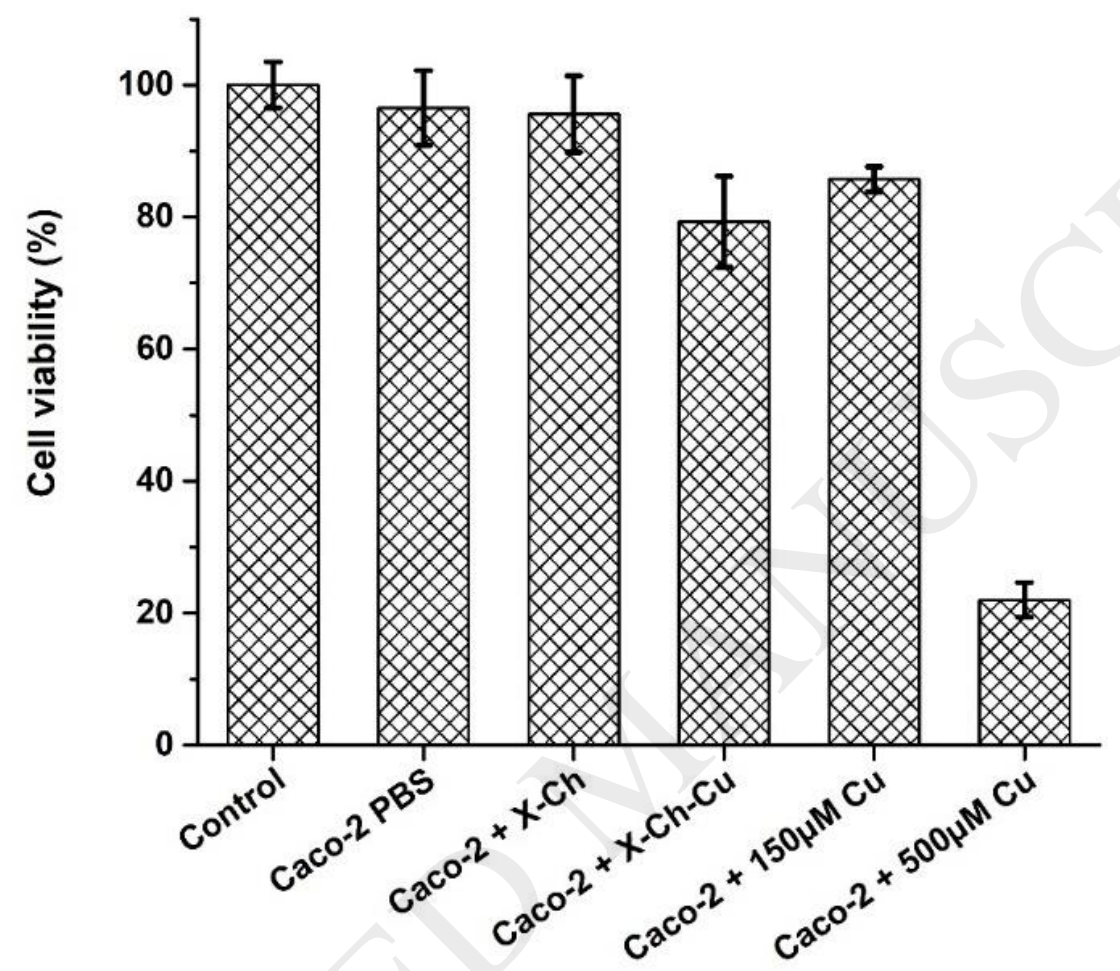

Fig. 3. MTS cell viability bioassay. Caco-2 cells were seeded in 96-well plates at a concentration of $2.0 \times 10^{4}$ cells $/ \mathrm{mL}$ for $48 \mathrm{~h}$. Then cells were incubated with: PBS (also used for curcumin dilution), $0.5 \mathrm{mg}$ Xanthan-Chitosan nanofibers (X-Ch), $0.5 \mathrm{mg}$ curcumin-loaded Xanthan-Chitosan nanofibers (X-Ch-Cu), $150 \mu \mathrm{M}$ curcumin diluted in PBS $(\mathrm{Cu})$, and $500 \mu \mathrm{M}$ curcumin diluted in PBS $(\mathrm{Cu})$. After $24 \mathrm{~h}$ incubation, the cell viability was evaluated through MTS assay. Data are the mean \pm SD of six independent experiments. 


\subsection{Evaluation of Caco-2 cell monolayers integrity}

To perform reliable in vitro permeability experiments across Caco-2 cell monolayers, the transport of non-radiolabeled markers, fluorescein and lucifer yellow, and the transepithelial electrical resistance measurements were conducted to quantitatively investigate the integrity and permeability of cell monolayers after 21 days growth on 12-mm polycarbonate inserts. The monolayers integrity is a fundamental determinant of the study of drugs transport via the intestinal membrane, especially when the passive transport of substances through tight junctions is involved (Srinivasan et al., 2015). Therefore, the AB and BA transepithelial transports of fluorescein (FLUO) and lucifer yellow (LY) across Caco-2 monolayers under a proton gradient were investigated (Fig. 4). The average of TEER values for Caco- 2 cell monolayers measured at $37{ }^{\circ} \mathrm{C}$ was $422 \pm 30 \Omega \mathrm{cm}^{2}$ and the TEER values of Caco-2 cell monolayers before and after transport of FLUO and LY were found to be in the range of 350-500 $\Omega \mathrm{cm}^{2}$ (Fig. 4a) indicating an "intermediate" tightness of the gastrointestinal epithelium, as established by the GI epithelia classification based on TEER values (Amidon, Lee, \& Topp, 2000). Fig. $4 \mathrm{~b}$ and $4 \mathrm{c}$ show the cumulative permeated amount of the two markers after apical-to-basolateral and basolateral-to-apical transport across Caco-2 cell monolayers in presence of a proton gradient ( $\mathrm{pH} 6.5$ in $\mathrm{A}$ and $\mathrm{pH} 7.4$ in B), and the FLUO and LY distribution within the cell model system, respectively. The permeation of fluorescein across the monolayers increased over time and it was higher when a lower $\mathrm{pH}$ of the donor solution was used. In fact, after $8 \mathrm{~h}$ the amount of fluorescein at the acceptor chamber was $20 \%$ and $12 \%$ for the $\mathrm{AB}$ and $\mathrm{BA}$ transport respectively, suggesting a pHdependent transport of fluorescein. Consequently, most of the fluorescein at the donor side was still found at time $=8 \mathrm{~h}(\sim 78 \%)$, and this value was even higher for BA transport. Only small amounts of FLUO were detected within the cell lysate and insert membrane (0.74 and $0.58 \%$, respectively). Contrarily, the permeation of LY was weakly affected by $\mathrm{pH}$ and the cumulative amounts transferred across cell monolayers were less than $1.5 \%$ for both $\mathrm{AB}$ and BA transports, resulting in a highly poor 
absorption of LY (98\% of the initial donor concentration remained there). The values of the apparent permeability coefficients of FLUO were $P_{a p p, A B}=9.52 \times 10^{-6}$ and $P_{a p p, B A}=1.89 \times 10^{-6} \mathrm{~cm} / \mathrm{s}$, whereas much lower values were calculated for the LY transport: $\mathrm{P}_{\mathrm{app}, \mathrm{AB}}=6.26 \times 10^{-7}$ and $\mathrm{P}_{\mathrm{app}, \mathrm{BA}}=1.46 \times 10^{-7}$ $\mathrm{cm} / \mathrm{s}$ (Fig. 4d). These results demonstrate that the different physical-chemical properties of FLUO and LY are strongly reflected in their permeation across the cell monolayers and the transport mechanism involved in the absorption. The main features of a compound influencing its permeation are $\log \mathrm{P}, \mathrm{pK}_{\mathrm{a}}$, molecular weight, and ionization (Table 1) (Camenisch, Folkers, \& van de Waterbeemd, 1996). Fluorescein is a small and lipophilic molecule $\left(\log \mathrm{P}_{\mathrm{o} / \mathrm{w}}=4.81\right)$ and possesses two ionization groups having a $\mathrm{pK}_{\mathrm{a} 1}=4.36$ and $\mathrm{pK}_{\mathrm{a} 2}=6.38$. By contrast, lucifer yellow is a small hydrophilic compound $\left(\log \mathrm{P}_{\mathrm{o} / \mathrm{w}}=-5.06\right)$ and has a $\mathrm{pK}_{\mathrm{a}}=-0.9$. According to the results presented in Fig. 4, $\mathrm{P}_{\text {app }}$ values of FLUO increased with the decreasing $\mathrm{pH}$ of the donor solution, at which the compound is ionized at a smaller extent, while the high hydrophilicity and ionization of LY prevent its absorption through cell monolayers. The apical membrane of polarized epithelial cell layers has a lipoid nature thus it restricts the transport of ions and hydrophilic molecules. Therefore, lipophilic compounds like FLUO, across the cell barrier through a passive transcellular transport following their $\mathrm{pH}$ partitioning into the apical membrane and diffusing through the cytoplasm reaching the basolateral membrane (Högerle \& Winne, 1983). For more hydrophilic compounds like LY, transcellular diffusion is often prevented and depending on the $\mathrm{pK}_{\mathrm{a}}$ of molecules at the donor $\mathrm{pH}$, the transport of these solutes across epithelial cells can occur via tight junctions (paracellular transport). In the light of these considerations, the results obtained from AB and BA transport of FLUO and LY suggested that the integrity and tightness of Caco- 2 cell monolayers after 21 days were maintained, and further studies using X-Ch-Cu nanofibers have been investigated using this approach. 
a)

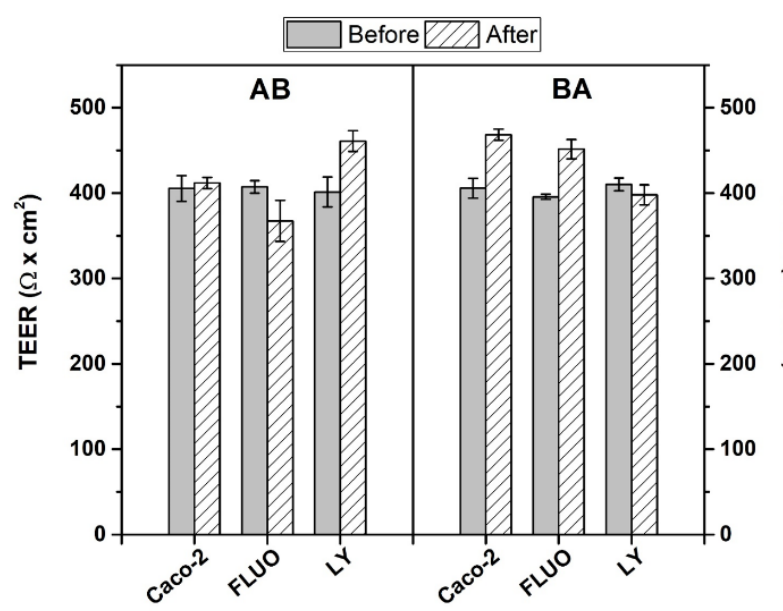

c)

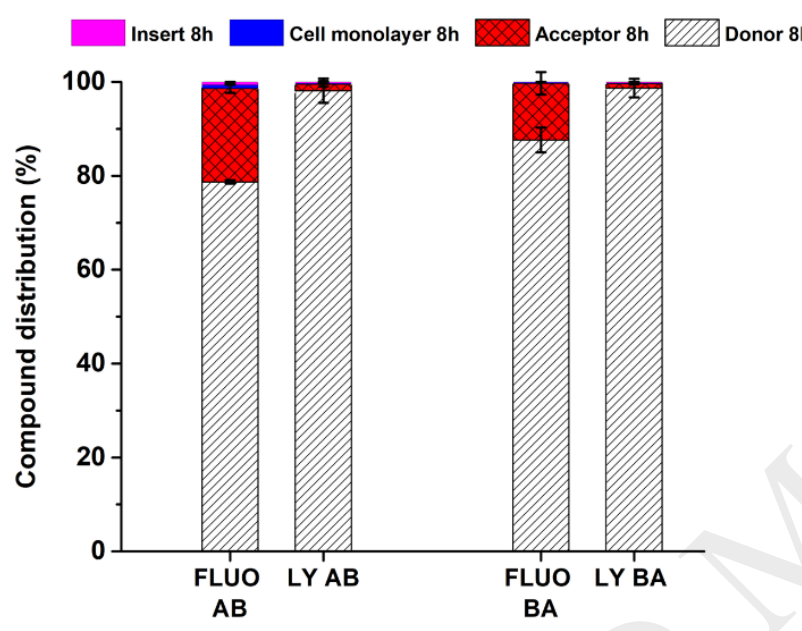

b)

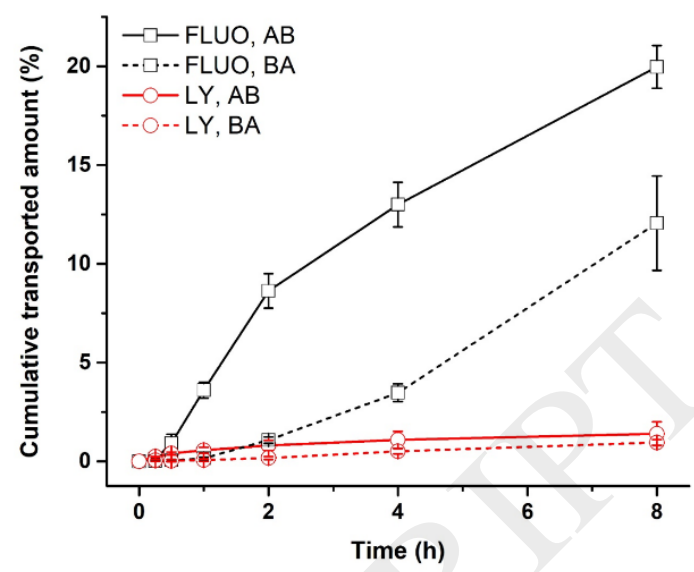

d)

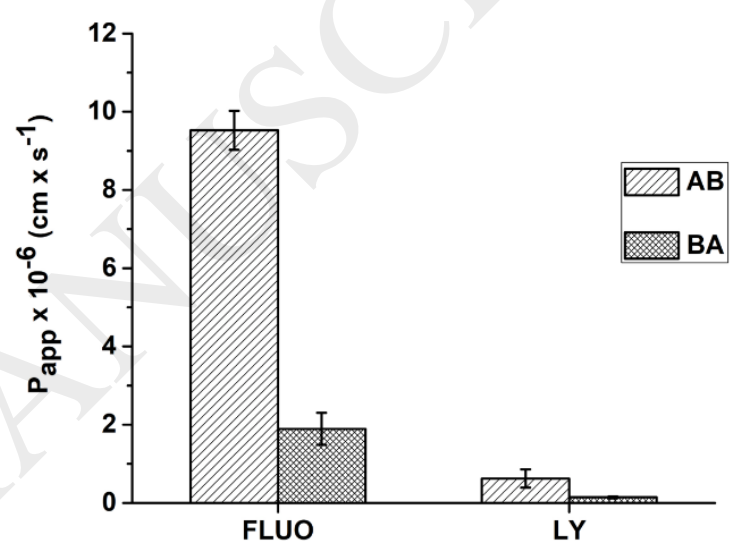

Fig. 4. Quantitative evaluation of Caco-2 cell monolayers integrity. Fluorescein (FLUO) and lucifer yellow (LY) were used as non-radiolabeled permeability markers and the transepithelial electrical resistance values (TEER) of cell monolayers were measured before and after apical-to-basolateral (AB) and basolateral-to-apical (BA) studies for a time interval of $8 \mathrm{~h}$. a) TEER values of Caco-2 monolayers incubated respectively with a transport medium, $1 \mathrm{mM}$ FLUO, and $870 \mu \mathrm{M} \mathrm{LY}$ at the donor chamber, before and after $\mathrm{AB}$ and $\mathrm{BA}$ transport processes. b) Percentage of the cumulative transported amount of FLUO and LY over time, for both AB and BA studies. c) FLUO and LY distribution after $8 \mathrm{~h}$ transport experiments in the acceptor chamber, donor chamber, Caco-2 cell monolayer, and insert membrane. d) Apparent permeability coefficient $\left(P_{a p p}\right)$ of FLUO and LY 
calculated for both $\mathrm{AB}$ and $\mathrm{BA}$ transports. All data are the mean $\pm \mathrm{SD}$ of three independent experiments.

\subsection{Caco-2 cell monolayers treatments}

The low aqueous solubility, poor intestinal absorption and extensive metabolism and excretion are crucial parameters that affect curcumin bioavailability. In order to overcome some of these limiting factors, Xanthan-Chitosan electrospun nanofibers as curcumin delivery system were produced and investigated. In the present study, the restricted use of chitosan as an in vitro absorption enhancer in epithelial cell monolayers was overcome by mixing the chitosan with xanthan gum polysaccharide. As reported by Dempe et al. (Dempe et al., 2013), Caco-2 cell monolayers express the enzymes involved in phase I and II metabolism of curcumin. In fact, curcumin metabolites such as hexahydroand octahydro-curcumin, as well as their glucuronide and sulfate conjugates were identified as major metabolites at the donor and acceptor side (Dempe et al., 2013). Thus, in the present study, the quantification of curcumin at the apical and basolateral side was conducted recording the absorbance of native curcumin at $420 \mathrm{~nm}$, and also measuring the absorbance of curcumin metabolites at $280 \mathrm{~nm}$, as suggested by Dempe et al. (Dempe et al., 2013). Therefore, the data obtained for curcumin transepithelial transport studies, include the contribution of both transported native curcumin and its metabolites.

The $24 \mathrm{~h}$ exposure of Caco-2 cell monolayers to $\mathrm{X}-\mathrm{Ch}$ and $\mathrm{X}-\mathrm{Ch}-\mathrm{Cu}$ nanofibers resulted in a cell viability $>90 \%$ and $\sim 80 \%$, respectively (Fig. 3). In addition to that, the incubation of cell monolayers with $150 \mu \mathrm{M}$ free $\mathrm{Cu}$ and $\mathrm{X}-\mathrm{Ch}-\mathrm{Cu}$ nanofibers ended up to a comparable cell viability value, indicating that the amount of curcumin loaded into the nanofibers was similar to the free curcumin $(150 \mu \mathrm{M})$, and that the small decrement in cell viability $(\sim 80 \%)$ was attributed to the curcumin dose 
and not to the presence of X-Ch nanofibers (>90\%). In order to investigate the presumed enhancement of curcumin absorption across epithelial cell monolayers in presence of Xanthan-Chitosan nanofibers, the $\mathrm{AB}$ and $\mathrm{BA}$ transport of free $\mathrm{Cu}(\mathrm{Cu}), \mathrm{X}-\mathrm{Ch}$ nanofibers + free $\mathrm{Cu}(\mathrm{X}-\mathrm{Ch}+\mathrm{Cu})$, and curcuminloaded X-Ch nanofibers (X-Ch-Cu) were performed (Fig. 5a and b). As depicted in the illustrations, the free curcumin and/or nanofibers were incubated at the donor chamber and the transported amount of curcumin was withdrawn from the acceptor side over a period of $8 \mathrm{~h}$ under a proton gradient. The addition of Xanthan-Chitosan nanofibers to free curcumin was found to enhance curcumin permeation of nearly 2-fold compared to free curcumin alone, and such enhancement was even higher for $\mathrm{X}-\mathrm{Ch}-\mathrm{Cu}$ nanofibers reaching 3.4-fold. For $\mathrm{X}-\mathrm{Ch}-\mathrm{Cu}$ nanofibers, the total amount of curcumin transported across cell monolayers for $\mathrm{AB}$ and $\mathrm{BA}$ transports was $32.81 \%$ and $46.94 \%$ of the releasable curcumin, respectively. The observed slight reduction of TEER values for AB transport of $\mathrm{X}-\mathrm{Ch}+\mathrm{Cu}$ and $\mathrm{X}-\mathrm{Ch}-\mathrm{Cu}$ was found to be more pronounced for BA transport of $\mathrm{X}-\mathrm{Ch}+\mathrm{Cu}$ and $\mathrm{X}-$ Ch-Cu (Fig. 5c and d). Taken together, the observed results suggest that the presence of XanthanChitosan nanofibers positively affect curcumin permeation since a 3-fold higher concentration of curcumin was detected in the acceptor chamber. The decrease in TEER values supports that the tight junctions were affected by the electrospun fibers, and direct contact between the fibers and cell monolayers. This is in agreement with our previous study on the permeation of a model protein (insulin) across Caco-2 cells upon contact with electrospun fish protein fibers (Stephansen, GarcíaDíaz, Jessen, Chronakis, \& Nielsen, 2015). Indeed, we found that direct interaction between the nanofibers and the monolayer induces changes in the tight junctions, and thus an increase in permeation at local hot spots on the epithelial barrier. Moreover, the reduction of TEER values could be also attributed in part to the presence of chitosan within the electrospun nanofibers, which is responsible for the tight junctions opening, thus promoting paracellular transport. In addition to that, no cell-damaging was detected after $24 \mathrm{~h}$ treatment with $\mathrm{X}-\mathrm{Ch}$ and $\mathrm{X}-\mathrm{Ch}-\mathrm{Cu}$. In fact, the effect of 
chitosan and its derivatives on Caco-2 cell monolayers has been extensively studied (Borchard et al., 1996; Kowapradit et al., 2010), and TEER measurements have shown that chitosan induces an immediate reduction of TEER in a dose-dependent effect on tight junction permeability. However, a recovery of TEER values in the time range of few hours up to one day could be observed after chitosan polymer solution removal (Borchard et al., 1996; Kowapradit et al., 2010). In these studies, a paracellular transport of $\left[{ }^{14} \mathrm{C}\right]$-mannitol across Caco-2 monolayers was recorded only when a certain TEER threshold value was reached (Borchard et al., 1996).

a)

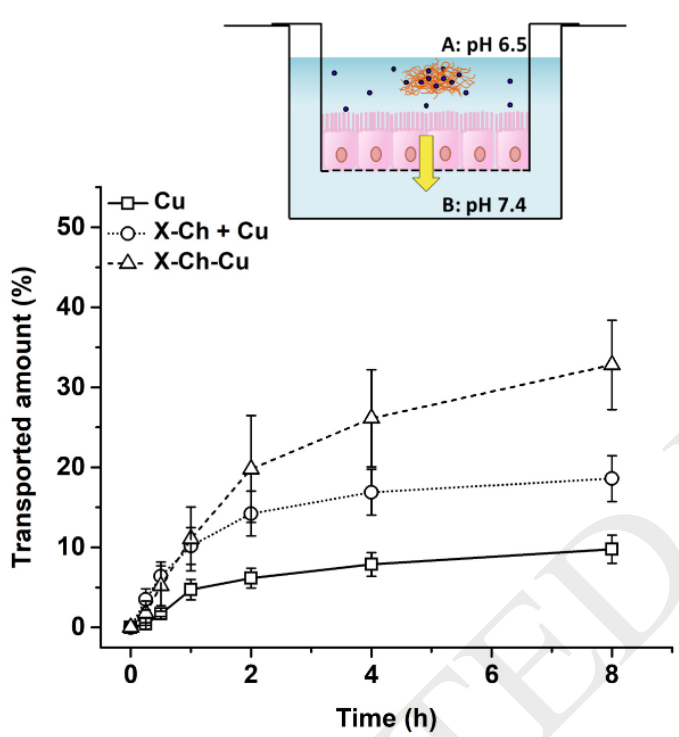

c)

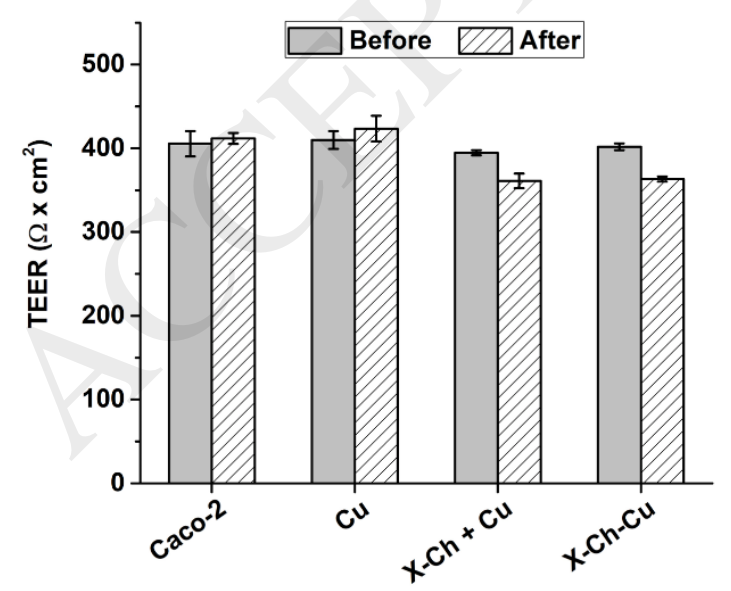

b)

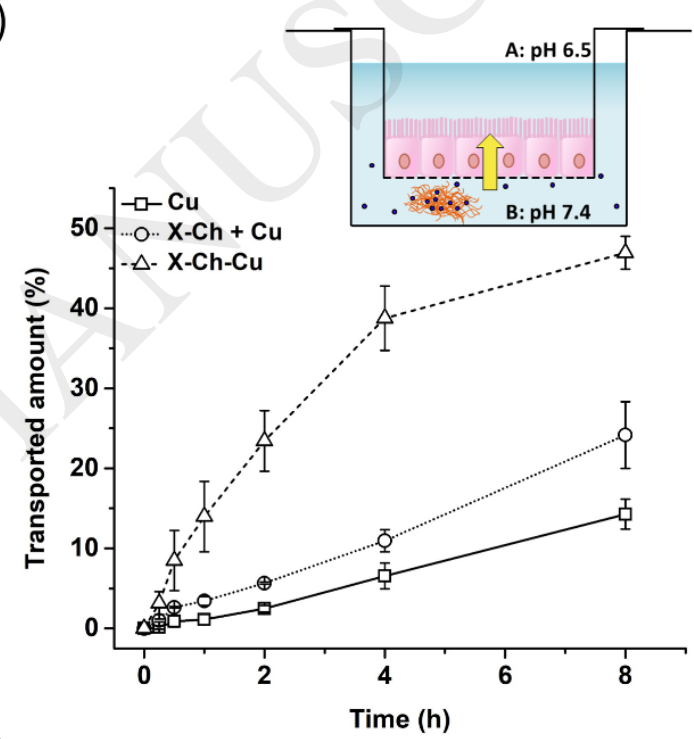

d)

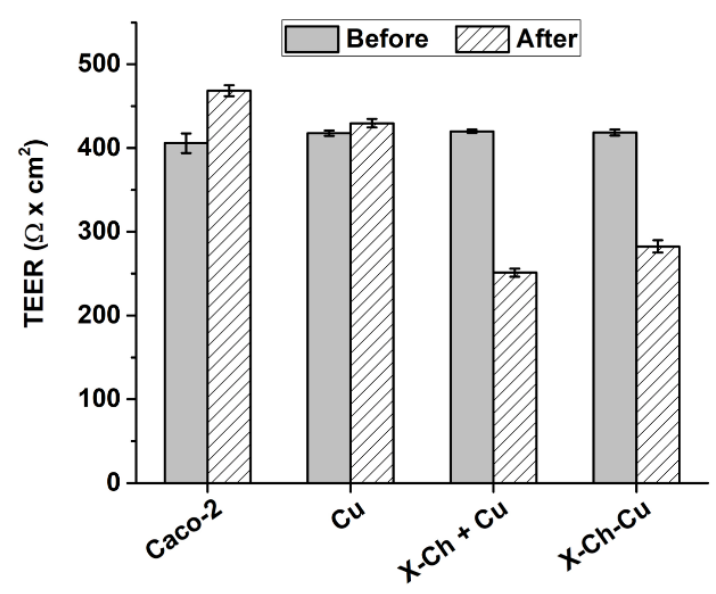


Fig. 5. Study of the transepithelial transport across Caco- 2 cell monolayers of free curcumin $(\mathrm{Cu}, 150$ $\mu \mathrm{M})$, free curcumin $(150 \mu \mathrm{M})+3.0 \mathrm{mg}$ Xanthan-Chitosan nanofibers $(\mathrm{X}-\mathrm{Ch}+\mathrm{Cu})$, and $9.0 \mathrm{mg}$ curcumin-loaded Xanthan-Chitosan nanofibers $(\mathrm{X}-\mathrm{Ch}-\mathrm{Cu}$, fibers amount that corresponded to 150 $\mu \mathrm{M}$ released curcumin) at the donor chamber. Apical-to-basolateral (AB) and basolateral-to-apical (BA) transport were conducted for a time interval of $8 \mathrm{~h}$ under a proton gradient, $\mathrm{pH}=6.5$ at the apical side and $\mathrm{pH}=7.4$ at the basolateral chamber. a) and b) Percentage of the transported amount of $\mathrm{Cu}$ over time for $\mathrm{AB}$ and BA studies, respectively. c) and d) TEER values of Caco-2 cell monolayers before and after $\mathrm{AB}$ and $\mathrm{BA}$ transport, respectively. All data are the mean $\pm \mathrm{SD}$ of three independent experiments.

The fate of curcumin during transepithelial transport in both $\mathrm{AB}$ and $\mathrm{BA}$ directions was monitored by quantifying (after $8 \mathrm{~h}$ ) the amount of curcumin in the donor and acceptor side, Caco-2 cell lysate, insert membrane, and within X-Ch nanofibers. Fig. 6a shows the distribution of curcumin in the above-mentioned compartments when free $\mathrm{Cu}, \mathrm{X}-\mathrm{Ch}+\mathrm{Cu}$, and $\mathrm{X}-\mathrm{Ch}-\mathrm{Cu}$ nanofibers were incubated in the donor chamber. Although significant amounts of curcumin were still detected in the donor side after $8 \mathrm{~h}$ transport, curcumin concentrations $\geq 10 \%$ of the donor initial concentration were detected in the acceptor side. Only small amounts of curcumin were found into cell lysate, $<3 \%$, and insert membrane, $<1.5 \%$, while considerable curcumin amounts remained loaded into X-Ch-Cu nanofibers even after $8 \mathrm{~h}$ release (28\% into $\mathrm{X}-\mathrm{Ch}-\mathrm{Cu}$ in the $\mathrm{AB}$ study, and $13 \%$ into $\mathrm{X}-\mathrm{Ch}-\mathrm{Cu}$ in the BA study). Nevertheless, the proposed curcumin delivery system showed the highest amount of curcumin permeating the epithelial cell monolayers with a $\mathrm{P}_{\mathrm{app}, \mathrm{AB}}=1.49 \times 10^{-5} \mathrm{~cm} / \mathrm{s}$ and a $\mathrm{P}_{\mathrm{app}}, \mathrm{BA}=7.00 \times 10^{-6}$ $\mathrm{cm} / \mathrm{s}$ (Fig. 6c), and a 2-fold permeability enhancement was measured when Xanthan-Chitosan nanofibers were added to a free curcumin solution in the donor side compared to free curcumin 
without fibers. In addition, after $8 \mathrm{~h}$, the morphology of the tested nanofibers was analyzed by microscopy (data not shown), and besides a loss of yellow-orange coloration due to the released curcumin, no morphological variations were observed.

a)

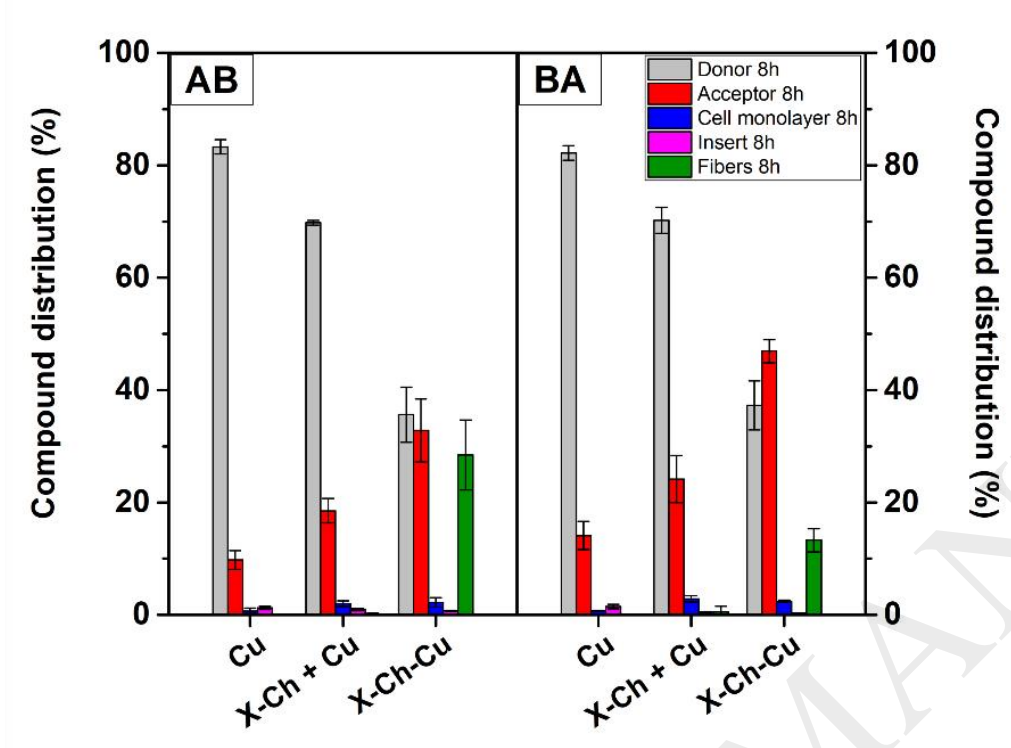

b)

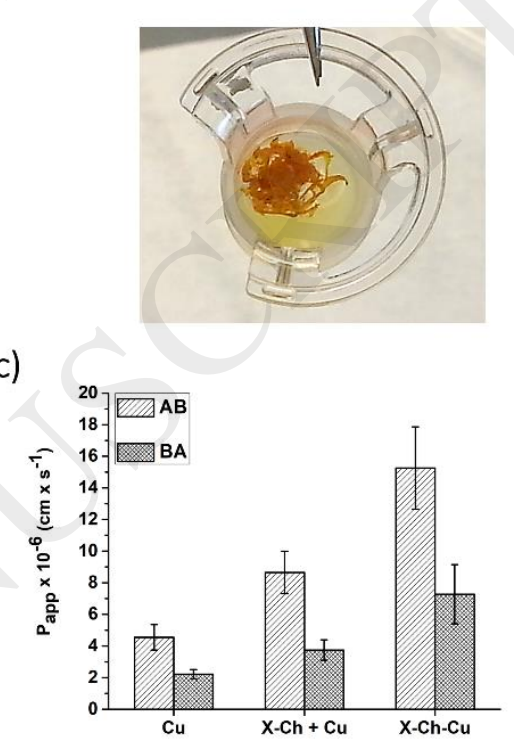

Fig. 6. Study of the transepithelial transport of $150 \mu \mathrm{M}$ free curcumin $(\mathrm{Cu}), 3.0 \mathrm{mg}$ Xanthan-Chitosan nanofibers $+150 \mu \mathrm{M}$ free $\mathrm{Cu}(\mathrm{X}-\mathrm{Ch}+\mathrm{Cu})$, and $9.0 \mathrm{mg}$ curcumin-loaded Xanthan-Chitosan nanofibers (X-Ch-Cu) across Caco-2 cell monolayers. a) $\mathrm{Cu}$ distribution after $8 \mathrm{~h}$ transport experiments in the acceptor chamber, donor chamber, Caco-2 cell monolayer, insert membrane, and within X-Ch nanofibers. b) Image of a Caco-2 cell monolayer cultured for 21 days in a 12-mm polycarbonate semipermeable membrane containing a solution of HBSS at pH 6.5 and $9.0 \mathrm{mg}$ X-Ch$\mathrm{Cu}$ nanofibers. The yellow medium indicates the presence of released curcumin from $\mathrm{X}-\mathrm{Ch}-\mathrm{Cu}$ nanofibers that has a strong orange color. c) Apparent permeability coefficient $\left(P_{a p p}\right)$ of Cu calculated for both $\mathrm{AB}$ and $\mathrm{BA}$ transports. All data are the mean $\pm \mathrm{SD}$ of three independent experiments. 


\section{Conclusions}

Uniform and homogeneous Xanthan-Chitosan nanofibers were fabricated using electrospinning processing and investigated as an encapsulation and delivery system of curcumin, a poor water soluble polyphenolic compound. It was found that $\mathrm{X}-\mathrm{Ch}-\mathrm{Cu}$ nanofibers remained stable in aqueous HBSS medium at different $\mathrm{pH}$ (6.5 and $\mathrm{pH}$ 7.4). Moreover, $\mathrm{X}-\mathrm{Ch}-\mathrm{Cu}$ nanofibers were incubated with Caco-2 cells, and cell viability, transepithelial transport and curcumin permeability properties across cell monolayers were investigated. After $24 \mathrm{~h}$ of incubation, the exposure of Caco- 2 cell monolayers to $\mathrm{X}-\mathrm{Ch}$ and $\mathrm{X}-\mathrm{Ch}-\mathrm{Cu}$ nanofibers resulted in a cell viability of $>90 \%$ and $\sim 80 \%$, respectively. A 3.4-fold increase of curcumin permeability was observed in the presence of X-Ch fibers, in comparison with free-curcumin. The X-Ch nanofibers interacted with intestinal Caco-2 cells and caused tight junctions opening, demonstrated by a decrease in TEER values, which promoted increased transepithelial permeation of curcumin without compromising cellular viability. Hence, the interactions between electrospun fibers and the epithelial cells, could be used to promote increased uptake of bioactives. Furthermore, in vivo experiments are required to fully demonstrate the efficiency of these nanofibers for oral delivery applications of poorly water-soluble compounds at the gastrointestinal tract.

\section{Acknowledgments}

The project was supported by a PhD stipend (to ES) from the Technical University of Denmark. Part of this work was also supported by the European Union funded project "Nano3Bio" (grant agreement no 613931) under FP7. 


\section{References}

Aftab, N., \& Vieira, A. (2009). Antioxidant activities of curcumin and combinations of this curcuminoid with other phytochemicals. Phytotherapy Research, 24(4), n/a-n/a. https://doi.org/10.1002/ptr.2960

Ak, T., \& Gülçin, İ. (2008). Antioxidant and radical scavenging properties of curcumin. ChemicoBiological Interactions, 174(1), 27-37. https://doi.org/10.1016/j.cbi.2008.05.003

Amidon, G. L., Lee, P. I., \& Topp, E. M. (2000). Transport processes in pharmaceutical systems. M. Dekker.

Anand, P., Kunnumakkara, A. B., Newman, R. A., \& Aggarwal, B. B. (2007). Bioavailability of Curcumin: Problems and Promises. Molecular Pharmaceutics, 4(6), 807-818. https://doi.org/10.1021/mp700113r

Araújo, F., \& Sarmento, B. (2013). Towards the characterization of an in vitro triple co-culture intestine cell model for permeability studies. International Journal of Pharmaceutics, 458(1), 128-134. https://doi.org/10.1016/j.ijpharm.2013.10.003

Artursson, P., Palm, K., \& Luthman, K. (2001). Caco-2 monolayers in experimental and theoretical predictions of drug transport. Advanced Drug Delivery Reviews, 46(1-3), 27-43. https://doi.org/10.1016/S0169-409X(00)00128-9

Balasubramanian, S., \& Eckert, R. L. (2004). Green Tea Polyphenol and Curcumin Inversely Regulate Human Involucrin Promoter Activity via Opposing Effects on CCAAT/Enhancerbinding Protein Function. Journal of Biological Chemistry, 279(23), 24007-24014. https://doi.org/10.1074/jbc.M314331200 
Berginc, K., Žakelj, S., Levstik, L., Uršič, D., \& Kristl, A. (2007). Fluorescein transport properties across artificial lipid membranes, Caco-2 cell monolayers and rat jejunum. European Journal of Pharmaceutics and Biopharmaceutics, 66(2), 281-285.

https://doi.org/10.1016/J.EJPB.2006.10.023

Blanco-Padilla, A., López-Rubio, A., Loarca-Piña, G., Gómez-Mascaraque, L. G., \& Mendoza, S. (2015). Characterization, release and antioxidant activity of curcumin-loaded amaranthpullulan electrospun fibers. LWT - Food Science and Technology, 1-8. https://doi.org/10.1016/j.lwt.2015.03.081

Borchard, G., Lueßen, H. L., de Boer, A. G., Verhoef, J. C., Lehr, C.-M., \& Junginger, H. E. (1996). The potential of mucoadhesive polymers in enhancing intestinal peptide drug absorption. III: Effects of chitosan-glutamate and carbomer on epithelial tight junctions in vitro. Journal of Controlled Release, 39(2-3), 131-138. https://doi.org/10.1016/0168$3659(95) 00146-8$

Camenisch, G., Folkers, G., \& van de Waterbeemd, H. (1996). Review of theoretical passive drug absorption models: historical background, recent developments and limitations. Pharmaceutica Acta Helvetiae, 71(5), 309-27.

Chanburee, S., \& Tiyaboonchai, W. (2017). Enhanced intestinal absorption of curcumin in Caco-2 cell monolayer using mucoadhesive nanostructured lipid carriers. Journal of Biomedical Materials Research Part B: Applied Biomaterials. https://doi.org/10.1002/jbm.b.33884

Cory, A. H., Owen, T. C., Barltrop, J. A., \& Cory, J. G. (1991). Use of an aqueous soluble tetrazolium/formazan assay for cell growth assays in culture. Cancer Communications, 3(7), 207-12. 
Cruz-Correa, M., Shoskes, D. A., Sanchez, P., Zhao, R., Hylind, L. M., Wexner, S. D., \& Giardiello, F. M. (2006). Combination Treatment With Curcumin and Quercetin of Adenomas in Familial Adenomatous Polyposis. Clinical Gastroenterology and Hepatology, 4(8), 10351038. https://doi.org/10.1016/j.cgh.2006.03.020

Cuomo, J., Appendino, G., Dern, A. S., Schneider, E., McKinnon, T. P., Brown, M. J., ... Dixon, B. M. (2011). Comparative Absorption of a Standardized Curcuminoid Mixture and Its Lecithin Formulation. Journal of Natural Products, 74(4), 664-669. https://doi.org/10.1021/np1007262

Dempe, J. S., Scheerle, R. K., Pfeiffer, E., \& Metzler, M. (2013). Metabolism and permeability of curcumin in cultured Caco-2 cells. Molecular Nutrition \& Food Research, 57(9), 1543-1549. https://doi.org/10.1002/mnfr.201200113

Deng, L., Kang, X., Liu, Y., Feng, F., \& Zhang, H. (2017). Effects of surfactants on the formation of gelatin nanofibres for controlled release of curcumin. Food Chemistry, 231, 70-77. https://doi.org/10.1016/j.foodchem.2017.03.027

Frank, J., Schiborr, C., Kocher, A., Meins, J., Behnam, D., Schubert-Zsilavecz, M., \& AbdelTawab, M. (2017). Transepithelial Transport of Curcumin in Caco-2 Cells Is significantly Enhanced by Micellar Solubilisation. Plant Foods for Human Nutrition, 72(1), 48-53. https://doi.org/10.1007/s11130-016-0587-9

Frenot, A., \& Chronakis, I. S. (2003). Polymer nanofibers assembled by electrospinning. Current Opinion in Colloid \& Interface Science, 8(1), 64-75. https://doi.org/10.1016/S13590294(03)00004-9

Fukuda, M., Peppas, N. A., \& McGinity, J. W. (2006). Properties of sustained release hot-melt extruded tablets containing chitosan and xanthan gum. International Journal of 
Pharmaceutics, 310(1-2), 90-100. https://doi.org/10.1016/j.ijpharm.2005.11.042

Gupta, S. C., Patchva, S., \& Aggarwal, B. B. (2013). Therapeutic roles of curcumin: lessons learned from clinical trials. The AAPS Journal, 15(1), 195-218. https://doi.org/10.1208/s12248-012$9432-8$

Hashimoto, K., Matsunaga, N., \& Shimizu, M. (1994). Effect of Vegetable Extracts on the Transepithelial Permeability of the Human Intestinal Caco-2 Cell Monolayer. Bioscience, Biotechnology, and Biochemistry, 58(7), 1345-1346. https://doi.org/10.1271/bbb.58.1345

Hoehle, S. I., Pfeiffer, E., Sólyom, A. M., \& Metzler, M. (2006). Metabolism of Curcuminoids in Tissue Slices and Subcellular Fractions from Rat Liver. Journal of Agricultural and Food Chemistry, 54(3), 756-764. https://doi.org/10.1021/jf058146a

Högerle, M. L., \& Winne, D. (1983). Drug absorption by the rat jejunum perfused in situ. Dissociation from the $\mathrm{pH}-$ partition theory and role of microclimate-pH and unstirred layer. Naunyn-Schmiedeberg's Archives of Pharmacology, 322(4), 249-55.

Hubatsch, I., Ragnarsson, E. G. E., \& Artursson, P. (2007). Determination of drug permeability and prediction of drug absorption in Caco-2 monolayers. Nature Protocols, 2(9), 2111-2119. https://doi.org/10.1038/nprot.2007.303

Ignatious, F., Sun, L., Lee, C.-P., \& Baldoni, J. (2010). Electrospun nanofibers in oral drug delivery. Pharmaceutical Research, 27(4), 576-588. https://doi.org/10.1007/s11095-010-00616

Kocher, A., Schiborr, C., Behnam, D., \& Frank, J. (2015). The oral bioavailability of curcuminoids in healthy humans is markedly enhanced by micellar solubilisation but not further improved by simultaneous ingestion of sesamin, ferulic acid, naringenin and xanthohumol. Journal of 
Functional Foods, 14, 183-191. https://doi.org/10.1016/J.JFF.2015.01.045

Konishi, Y., Hagiwara, K., \& Shimizu, M. (2002). Transepithelial Transport of Fluorescein in Caco-2 Cell Monolayers and Use of Such Transport in In Vitro Evaluation of Phenolic Acid Availability. Bioscience, Biotechnology, and Biochemistry, 66(11), 2449-2457. https://doi.org/10.1271/bbb.66.2449

Kowapradit, J., Opanasopit, P., Ngawhirunpat, T., Apirakaramwong, A., Rojanarata, T., Ruktanonchai, U., \& Sajomsang, W. (2010). In vitro Permeability Enhancement in Intestinal Epithelial Cells (Caco-2) Monolayer of Water Soluble Quaternary Ammonium Chitosan Derivatives. AAPS PharmSciTech, 11(2), 497-508. https://doi.org/10.1208/s12249-010-9399-7

Kulkarni, N., Wakte, P., \& Naik, J. (2015). Development of floating chitosan-xanthan beads for oral controlled release of glipizide. International Journal of Pharmaceutical Investigation, 5(2), 73-80. https://doi.org/10.4103/2230-973X.153381

Lee, W.-H., Loo, C.-Y., Young, P. M., Traini, D., Mason, R. S., \& Rohanizadeh, R. (2014). Recent advances in curcumin nanoformulation for cancer therapy. Expert Opinion on Drug Delivery, 11(8), 1183-1201. https://doi.org/10.1517/17425247.2014.916686

Li, X., Kanjwal, M. A., Lin, L., \& Chronakis, I. S. (2013). Electrospun polyvinyl-alcohol nanofibers as oral fast-dissolving delivery system of caffeine and riboflavin. Colloids and Surfaces B: Biointerfaces, 103, 182-188. https://doi.org/10.1016/j.colsurfb.2012.10.016

Lin, T.-C., Lin, F.-H., \& Lin, J.-C. (2012). In vitro feasibility study of the use of a magnetic electrospun chitosan nanofiber composite for hyperthermia treatment of tumor cells. Acta Biomaterialia, 8(7), 2704-2711. https://doi.org/10.1016/j.actbio.2012.03.045

Merlusca, I. P., Plamadeala, P., Girbea, C., \& Popa, I. M. (2016). Xanthan-Chitosan Complex As a 
Potential Protector Against Injurious Effects of Neomycin. Cellulose Chemistry and Technology, 50(5-6), 577-583.

Naruhashi, K., Kurahashi, Y., Fujita, Y., Kawakita, E., Yamasaki, Y., Hattori, K., ... Shibata, N. (2011). Comparison of the expression and function of ATP binding cassette transporters in Caco-2 and T84 cells on stimulation by selected endogenous compounds and xenobiotics. Drug Metabolism and Pharmacokinetics, 26(2), 145-53.

Perrone D, Ardito F, Giannatempo G, Dioguardi M,Troiano G, Lo Russo L, De Lillo A, Laino L, L. M. L. (2015). Biological and therapeutic activities, and anticancer properties of curcumin. Experimental and Therapeutic Medicine, 10(5), 1615-1623. https://doi.org/10.3892/etm.2015.2749

Pfeiffer, E., Hoehle, S. I., Walch, S. G., Riess, A., Sólyom, A. M., \& Metzler, M. (2007). Curcuminoids Form Reactive Glucuronides In Vitro. Journal of Agricultural and Food Chemistry, 55(2), 538-544. https://doi.org/10.1021/jf0623283

Pinto, M., Robineleon, S., Appay, M. D., Kedinger, M., Triadou, N., Dussaulx, E., ... Assmann, P. F. (1983, January 1). Enterocyte-like differentiation and polarization of the human-colon carcinoma cell-line Caco-2 in culture. Retrieved from https://www.scienceopen.com/document?vid=07f3fdcd-c23c-47d4-ad63-105346ef5453, Biol. cell 47, 323-330.

Popa, N., Novac, O., Profire, L., Lupusoru, C. E., \& Popa, M. I. (2010). Hydrogels based on chitosan-xanthan for controlled release of theophylline. Journal of Materials Science: Materials in Medicine, 21(16), 1241-1248. https://doi.org/10.1007/s10856-009-3937-4

Portero, A., Remuñán-López, C., \& Nielsen, H. M. (2002). The potential of chitosan in enhancing 
peptide and protein absorption across the TR146 cell culture model-an in vitro model of the buccal epithelium. Pharmaceutical Research, 19(2), 169-74.

Sanem Argin-Soysala, Peter Kofinasb, Y. M. Lo. (2009). Effect of complexation conditions on xanthan-chitosan polyelectrolyte complex gels. Food Hydrocolloids, 23(3), 202-209. https://doi.org/10.17306/J.AFS.2015.3.22

Schiborr, C., Kocher, A., Behnam, D., Jandasek, J., Toelstede, S., \& Frank, J. (2014). The oral bioavailability of curcumin from micronized powder and liquid micelles is significantly increased in healthy humans and differs between sexes. Molecular Nutrition \& Food Research, 58(3), 516-527. https://doi.org/10.1002/mnfr.201300724

Sharma, R. A., Gescher, A. J., \& Steward, W. P. (2005). Curcumin: The story so far. European Journal of Cancer, 41(13), 1955-1968. https://doi.org/10.1016/j.ejca.2005.05.009

Sharma, R. A., Steward, W. P., \& Gescher, A. J. (2007). PHARMACOKINETICS AND PHARMACODYNAMICS OF CURCUMIN. In The Molecular Targets and Therapeutic Uses of Curcumin in Health and Disease (Vol. 595, pp. 453-470). Boston, MA: Springer US. https://doi.org/10.1007/978-0-387-46401-5_20

Shekarforoush, E., Faralli, A., Ndoni, S., Mendes, A. C., \& Chronakis, I. S. (2017). Electrospinning of Xanthan Polysaccharide. Macromolecular Materials and Engineering, 201700067, 1700067. https://doi.org/10.1002/mame.201700067

Shekarforoush, E., Mendes, A., Baj, V., Beeren, S., \& Chronakis, I. (2017). Electrospun Phospholipid Fibers as Micro-Encapsulation and Antioxidant Matrices. Molecules, 22(10), 1708. https://doi.org/10.3390/molecules22101708

Shekarforoush E., Ajalloueian F., Zeng G. Mendes A.C., Chronakis I.S. (2018) Electrospun 
Xanthan gum-Chitosan nanofibers as delivery carrier of hydrophobic bioactives, Materials Letters, https://doi.org/10.1016/j.matlet.2018.06.033

Shoba, G., Joy, D., Joseph, T., Majeed, M., Rajendran, R., \& Srinivas, P. (1998). Influence of Piperine on the Pharmacokinetics of Curcumin in Animals and Human Volunteers. Planta Medica, 64(04), 353-356. https://doi.org/10.1055/s-2006-957450

Srinivasan, B., Kolli, A. R., Esch, M. B., Abaci, H. E., Shuler, M. L., \& Hickman, J. J. (2015). TEER Measurement Techniques for In Vitro Barrier Model Systems. Journal of Laboratory Automation, 20(2), 107-126. https://doi.org/10.1177/2211068214561025

Stephansen, K., García-Díaz, M., Jessen, F., Chronakis, I. S., \& Nielsen, H. M. (2015). Bioactive protein-based nanofibers interact with intestinal biological components resulting in transepithelial permeation of a therapeutic protein. International Journal of Pharmaceutics, 495(1), 58-66. https://doi.org/10.1016/j.ijpharm.2015.08.076

Tønnesen, H. H., \& Karlsen, J. (1985). Studies on curcumin and curcuminoids. VI. Kinetics of curcumin degradation in aqueous solution. Zeitschrift Fur Lebensmittel-Untersuchung UndForschung, 180(5), 402-4.

Usta, M., Wortelboer, H. M., Vervoort, J., Boersma, M. G., Rietjens, I. M. C. M., van Bladeren, P. J., \& Cnubben, N. H. P. (2007). Human Glutathione S-Transferase-Mediated Glutathione Conjugation of Curcumin and Efflux of These Conjugates in Caco-2 Cells. Chemical Research in Toxicology, 20(12), 1895-1902. https://doi.org/10.1021/tx7002245

Vega-Lugo A. C., Lim, L. T. (2012), Effects of poly(ethylene oxide) and pH on the electrospinning of whey protein isolate. J. Polym. Sci., Part B: Polym. Phys. 50, 1188. https://doi.org/10.1002/polb.23106 
Verma, S. P., Salamone, E., \& Goldin, B. (1997). Curcumin and Genistein, Plant Natural Products, Show Synergistic Inhibitory Effects on the Growth of Human Breast Cancer MCF-7 Cells Induced by Estrogenic Pesticides. Biochemical and Biophysical Research Communications, 233(3), 692-696. https://doi.org/10.1006/bbrc.1997.6527

Wahlang, B., Pawar, Y. B., \& Bansal, A. K. (2011). Identification of permeability-related hurdles in oral delivery of curcumin using the Caco-2 cell model. European Journal of Pharmaceutics and Biopharmaceutics, 77(2), 275-282. https://doi.org/10.1016/j.ejpb.2010.12.006

Wang, C. S., Natale, G., Virgilio, N., \& Heuzey, M. C. (2016). Synergistic gelation of gelatin B with xanthan gum. Food Hydrocolloids, 60, 374-383. https://doi.org/10.1016/j.foodhyd.2016.03.043

Wang, Y. J., Pan, M. H., Cheng, A. L., Lin, L. I., Ho, Y. S., Hsieh, C. Y., \& Lin, J. K. (1997). Stability of curcumin in buffer solutions and characterization of its degradation products. Journal of Pharmaceutical and Biomedical Analysis, 15(12), 1867-76.

Yee, S. (1997). In vitro permeability across Caco-2 cells (colonic) can predict in vivo (small intestinal) absorption in man--fact or myth. Pharmaceutical Research, 14(6), 763-6.

Zorofchian Moghadamtousi, S., Abdul Kadir, H., Hassandarvish, P., Tajik, H., Abubakar, S., \& Zandi, K. (2014). A Review on Antibacterial, Antiviral, and Antifungal Activity of Curcumin. BioMed Research International, 2014, 1-12. https://doi.org/10.1155/2014/186864 